\title{
Plio-Quaternary extensional tectonics of the Central Anatolian Plateau: a case study from the Tuz Gölï Basin, Turkey
}

\author{
Erman ÖZSAYIN $^{1{ }^{1} \star}$, T. Attila ÇINNER ${ }^{1}$, F. Bora ROJAY ${ }^{2}$, R. Kadir DİRİK ${ }^{1}$, Daniel MELNICK ${ }^{3}$, David FERNÁNDEZ-BLANCO ${ }^{4}$, \\ Giovanni BERTOTTI ${ }^{4,5}$, Taylor F. SCHILDGEN ${ }^{3}$, Yannick GARCIN ${ }^{3}$, Manfred R. STRECKER ${ }^{3}$, Masafumi SUDO ${ }^{3}$ \\ ${ }^{1}$ Department of Geological Engineering, Hacettepe University, 06800 Ankara, Turkey \\ ${ }^{2}$ Department of Geological Engineering, Middle East Technical University, 06800 Ankara, Turkey \\ ${ }^{3}$ Institute of Earth and Environmental Science, Potsdam University, 14476 Potsdam, Germany \\ ${ }^{4}$ Faculty of Earth and Life Sciences, Vrije University, Amsterdam, the Netherlands \\ ${ }^{5}$ Department of Geotechnology, Delft University of Technology, 2628 CN Delft, the Netherlands
}

\author{
Received: 16.10 .2012
}

- Accepted: 11.02 .2013

- $\quad$ Published Online: 26.08 .2013

- Printed: 25.09 .2013

\begin{abstract}
The Tuz Gölü Basin is the largest sedimentary depression located at the center of the Central Anatolian Plateau, an extensive, low-relief region with elevations of ca. $1 \mathrm{~km}$ located between the Pontide and Tauride mountains. Presently, the basin morphology and sedimentation processes are mainly controlled by the extensional Tuz Gölü Fault Zone in the east and the transtensional İnönüEskişehir Fault System in the west. The purpose of this study is to contribute to the understanding of the Plio-Quaternary deformation history and to refine the timing of the latest extensional phase of the Tuz Gölü Basin. Field observations, kinematic analyses, interpretations of seismic reflection lines, and ${ }^{40} \mathrm{Ar} /{ }^{39} \mathrm{Ar}$ dating of a key ignimbrite layer suggest that a regional phase of NNW-SSE to NE-SW contraction ended by $6.81 \pm 0.24 \mathrm{Ma}$ and was followed by N-S to NE-SW extension during the Pliocene-Quaternary periods. Based on sedimentological and chronostratigraphic markers, the average vertical displacement rates over the past 5 or $3 \mathrm{Ma}$ with respect to the central part of Tuz Gölü Lake are 0.03 to $0.05 \mathrm{~mm} /$ year for the fault system at the western flank of the basin and 0.08 to $0.13 \mathrm{~mm} /$ year at the eastern flank. Paleo-shorelines of the Tuz Gölü Lake, vestiges of higher lake levels related to Quaternary climate change, are important strain markers and were formed during Last Glacial Maximum conditions as indicated by a radiocarbon age of $21.8 \pm 0.4 \mathrm{ka}$ BP obtained from a stromatolitic crust. Geomorphic observations and deformed lacustrine shorelines suggest that the main strand of the Tuz Gölü Fault Zone straddling the foothills of the Şereflikoçhisar-Aksaray range has not been active during the Holocene. Instead, deformation appears to have migrated towards the interior of the basin along an offshore fault that runs immediately west of Şereflikoçhisar Peninsula. This basinward migration of deformation is probably associated with various processes acting at the lithospheric scale, such as plateau uplift and/or microplate extrusion.
\end{abstract}

Key words: Central Anatolia, Tuz Gölü Basin, orogenic plateau evolution, extensional tectonics, kinematic analysis, lake shoreline

\section{Introduction}

Orogenic plateaus are high-elevation, low-relief regions typically bounded by steep mountain belts. The Himalayas, Central Andes, North America Cordillera, and Central Anatolian Plateau (CAP) host well-known plateaus characterized by internally drained domains in their centers, often associated with neotectonic extensional tectonism (e.g., Whitney \& Dilek 1997; Dilek et al. 1999; Dilek \& Whitney 2000; Jaffey \& Robertson 2001, 2005). The modern morphotectonic features of the CAP have resulted from the westward escape of the Anatolian microplate along the North and East Anatolian Fault Systems (Şengör 1979; Şengör \& Yllmaz 1981; Barka 1992) and probably also from deeper lithosphericscale processes associated with tears and break-off of

\footnotetext{
*Correspondence: eozsayin@hacettepe.edu.tr
}

the Tethyan slab (Faccenna et al. 2001, 2006; Gans et al. 2009; Biryol et al. 2011; Cosentino et al. 2012; Schildgen et al. 2012b) and subsequent changes in upper mantle convection (Boschi et al. 2010; Faccenna \& Becker 2010; Genç \& Yürür 2010). Plate boundary interactions along the North Anatolian Fault during this neotectonic regime appear to have uplifted the northern plateau margin associated with the formation of a bivergent orogenic wedge (Yildırım et al. 2011), while lithospheric slab and upper mantle processes appear to have uplifted the southern plateau margin (Cosentino et al. 2012; Schildgen et al. 2012a, 2012b). These crustal and subcrustal processes not only affected the topography of the CAP, but also likely influenced its climate by producing orographic barriers to moisture-bearing atmospheric circulation (e.g., Schemmel 
et al. 2013), which probably had an important influence on deposition in interior sedimentary basins.

The Tuz Gölü Basin is the largest intracontinental basin of the CAP. The basin history records spatial and temporal changes in tectonics and sedimentation since the Late Cretaceous and thus constitutes an important archive to assess regional tectonic processes. The basin has been studied in terms of its paleotectonic setting, sedimentary processes, and hydrocarbon potential (Rigo de Righi \& Cortesini 1959; Arıkan 1975; Ünalan et al. 1976; Görür \& Derman 1978; Uygun et al. 1982; Görür et al. 1984; Çemen \& Dirik 1992; Göncüoğlu et al. 1992, 1996; Çemen et al. 1999; Derman et al. 2003; Dirik \& Erol 2003; Genç \& Yürür 2010, and references therein). Additionally, several investigations have dealt with the neotectonic activity of the fault systems that have controlled the youngest phase of deformation in the Tuz Gölü Basin, which is largely considered to be extensional (Koçyiğit 2003; Dirik et al. 2005; Özsayın \& Dirik 2005, 2007, 2011; Özsayın 2007; Kürçer \& Gökten 2011; Kürçer et al. 2011).

Despite the large number of studies devoted to understanding the tectonic and sedimentary evolution of the Tuz Gölü Basin, the timing of the latest extensional phase has still not been well defined. Therefore, the aim of this paper is to contribute to the understanding of the Plio-Quaternary deformation history of the Tuz Gölü Basin and surroundings by presenting new field observations, geochronologic and kinematic data, interpretation of seismic profiles, and fault slip rates from chronostratigraphic markers.

\section{Tectonic and geomorphic setting of the Tuz Gölü Basin}

\subsection{Regional neotectonic framework}

The present-day tectonic setting of Central Anatolia emerges from the convergence between the African and Arabian plates and the relatively stable Eurasian plate (Şengör \& Yllmaz 1981; Şengör et al. 1985), associated episodes of protracted shortening, and superposed extensional processes. Four main structural systems bound the Anatolian microplate. First, the retreating Aegean arc and the stable Cyprian arc mark the subduction of the African Plate beneath the Anatolian microplate (Papazachos \& Comninakis 1971; McKenzie 1978; Şengör \& Yllmaz 1981; Meulenkamp et al. 1988; Mart \& Woodside 1994). Second, the sinistral Dead Sea Fault System accommodates differential motion between the African Plate and the relatively fast Arabian Plate (Şengör \& Yllmaz 1981; Gülen et al. 1987; De Mets et al. 1990; Barka \& Reilinger 1997; Reilinger et al. 1997). Finally, the contraction between the principal lithospheric plates is balanced by the western escape of the Anatolian microplate along the North and East Anatolian fault systems (Şengör 1979; Şengör \& Yllmaz 1981; Barka 1992) (Figure 1a).
There are also some second-order tectonic features dividing the Anatolian microplate, especially in its central part. The İnönü-Eskişehir Fault System along with the Akşehir, Altınekin, and Tuz Gölü fault zones are the most important structures that constitute the transition between the west Anatolian extensional province and the east Anatolian contractional province (Arıkan 1975; Yetiş 1978, 1984; Yetiş \& Demirkol 1984; Şengör et al. 1985; Dirik \& Göncüoğlu 1996; Koçyiğit \& Beyhan 1998; Çemen et al. 1999; Koçyiğit et al. 2001; Dirik \& Erol 2003).

The WNW- to NW-striking İnönü-Eskişehir Fault System is a mega shear zone composed of 5 fault zones that extend along strike for $400 \mathrm{~km}$ (Figure 1a). The Eskişehir Fault Zone constitutes the western to central part (Altunel \& Barka 1998; Ocakoğlu \& Açıkalın 2009). The system branches into 3 fault zones at the eastern part, namely the Ilica, Yeniceoba, and Cihanbeyli fault zones (Koçyiğit 1991; Çemen et al. 1999; Dirik \& Erol 2003; Dirik et al. 2005; Koçyiğit 2003; Özsayın \& Dirik 2007, 2011) (Figure 1b). The Sultanhanı Fault Zone constitutes the southeastern part of the İnönü-Eskişehir Fault System (Özsayın \& Dirik 2005, 2007, 2011).

The NW-striking Tuz Gölü Fault Zone is composed of several NW-trending segments that run along the eastern margin of Tuz Gölü Lake for approximately 135 km (Arıkan 1975; Şengör et al. 1985; Dirik \& Göncüoğlu 1996; Çemen et al. 1999; Dirik \& Erol 2003) (Figure 1b).

The NNE-striking Altınekin Fault Zone is approximately $100 \mathrm{~km}$ long (Dirik \& Erol 2003). Özsayın \& Dirik (2011) defined this zone as a transfer fault that balances the extension between fault zones within the İnönü-Eskişehir Fault System.

Several studies have interpreted the kinematics of the fault zones in the Tuz Gölü Basin. Dhont et al. (1998) proposed an E-W to NE-SW extension to the SE part of the basin that was initiated during the Late Miocene and is associated with relative regional movement of the Anatolian Plate along a detachment fault. Koçyiğit (2003) suggested dextral strike slip deformation along the Tuz Gölü Fault Zone. Derman et al. (2003) suggested a pre-Neotectonic period (post-Eocene-pre-Quaternary period) of sinistral strike slip along the Tuz Gölü Fault Zone, followed by post-Pliocene normal faulting.

\subsection{Stratigraphy}

The sedimentary succession in the Tuz Gölü Basin starts with Upper Cretaceous-Paleocene terrestrial clastics and Eocene marine sediments deposited over a crystalline basement composed of metamorphic rocks and ophiolitic mélange units (Ünalan et al. 1976; Görür \& Derman 1978; Dellaloğlu \& Aksu 1984; Görür et al. 1984; Duru \& Gökçen 1985; Özcan et al. 1989, 1990a, 1990b; Göncüoğlu et al. 1991, 1992, 1996; Koçyiğit 1991, 1992; Çemen et al. 1999; Dirik \& Erol 2003) (Figure 2). The Eocene sequence is 


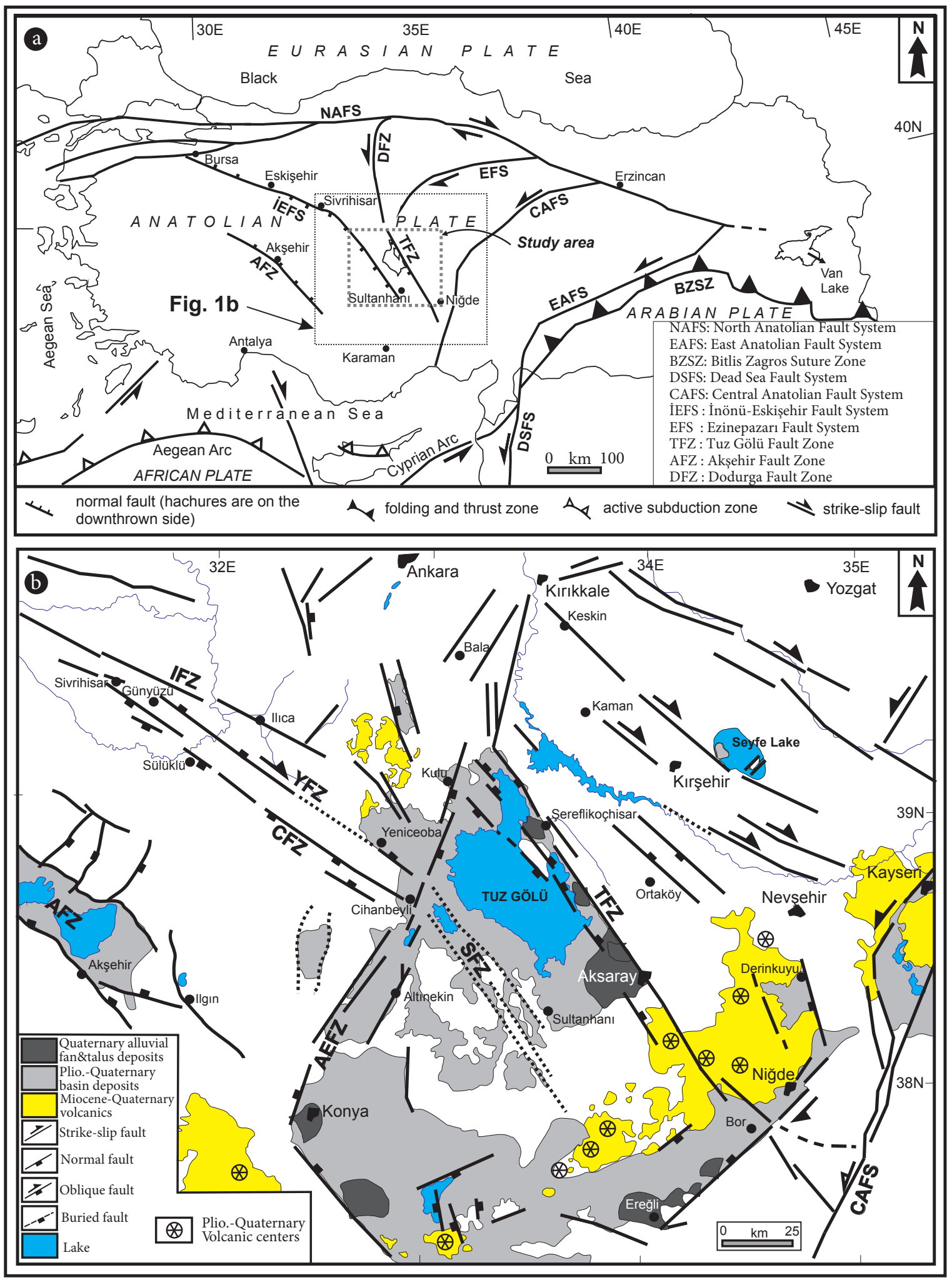

Figure 1. (a) A simplified map showing the major neotectonic structures in Turkey and the surrounding areas and (b) a tectonic map of the study area and the surrounding regions (AFZ: Akşehir Fault Zone, AEFZ: Altınekin Fault Zone, IFZ: Ilıca Fault Zone, YFZ: Yeniceoba Fault Zone, CFZ: Cihanbeyli Fault Zone, TFZ: Tuz Gölü Fault Zone, CAFS: Central Anatolian Fault System) (modified from Göncüoğlu et al. 1996). 


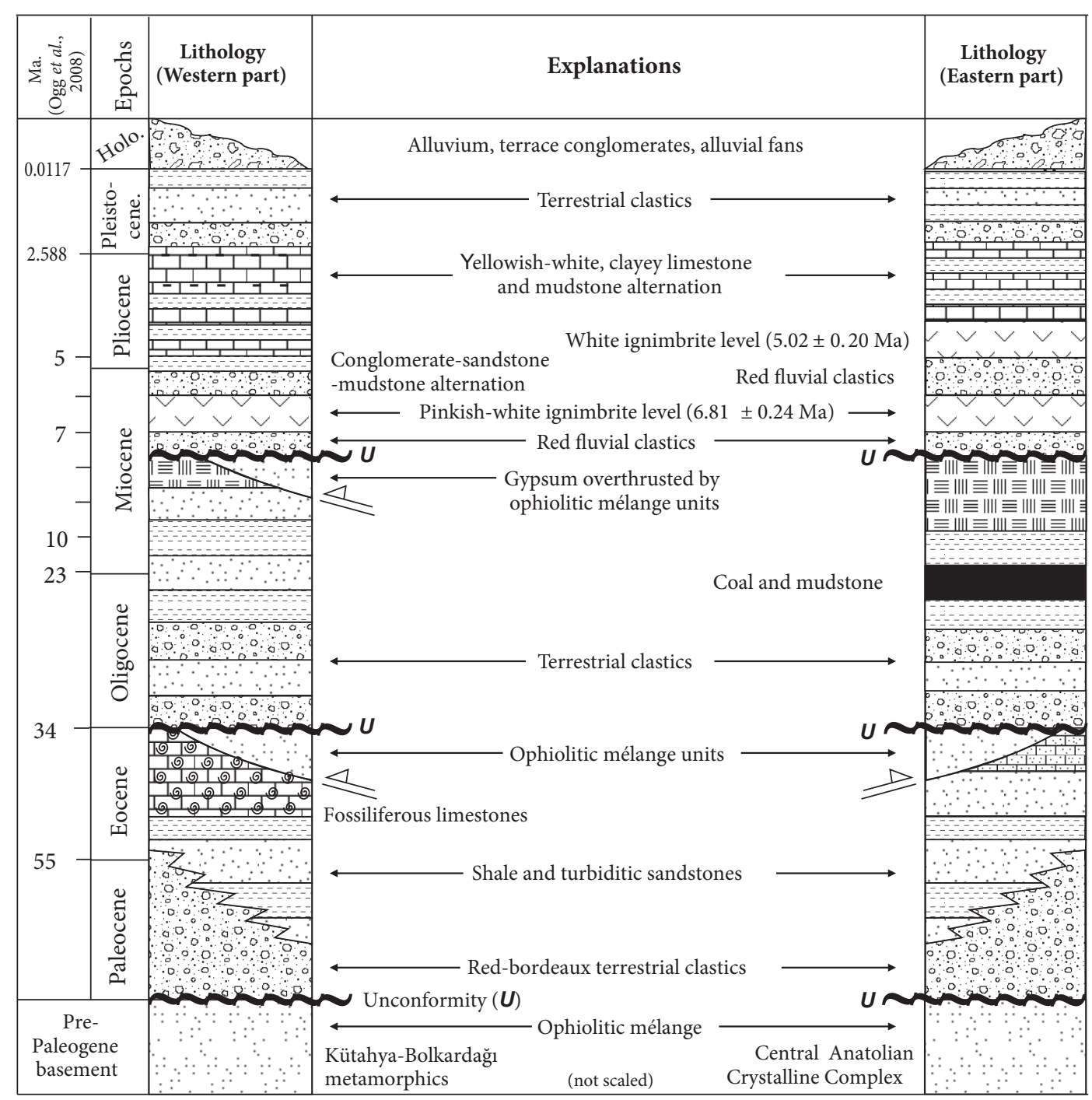

Figure 2. Tectono-stratigraphic section of the Tuz Gölü Basin.

sealed by thin- to medium-bedded evaporites of Oligocene age with an angular unconformity (Figure 2). Continental clastics including red-yellow, medium- to thick-bedded conglomerate and sandstone alternations make up the uppermost levels of the Oligocene sequence (Göncüoğlu et al. 1992, 1996; Çemen et al. 1999; Dirik \& Erol 2003).

Upper Miocene-Pliocene units that are composed of grayish, thin- to medium-bedded conglomeratesandstone-mudstone alternations cover the older rocks via an angular unconformity (Figure 2). They are overlain by a pinkish-white ignimbrite level, which is in turn overlain by a cross-bedded sandstone-mudstone alternation (Göncüoğlu et al. 1992, 1996) on the western side of the basin and by red clastics on the eastern side. At the eastern part of the Tuz Gölü Lake, these units are overlain by a white ignimbrite layer. Yellowish-white fossiliferous clayey limestones and green mudstones constitute the uppermost parts of this sequence in the Tuz Gölü Basin. This succession is unconformably overlain by Quaternary terrace and alluvial fan deposits and evaporites of Tuz Gölü Lake. In this paper, the pre-Upper Miocene units are regarded as bedrock units, while the Upper Miocene and younger units are referred to as cover rocks.

2.3 Geomorphic and stratigraphic setting of Pleistocene shorelines of the Tuz Gölü Basin

Tuz Gölü Lake fills an internally drained depression at an elevation of $906 \mathrm{~m}$ bounded by the AksarayŞereflikoçhisar range to the east. The present water depth of Tuz Gölü Lake is only 2 $\mathrm{m}$, but a series of near-shore sedimentary deposits and geomorphic features imply that there were higher water levels in the past. Erol (1969) first described such features and inferred that former 
lake highstands occurred during the Late Pliocene and Pleistocene. This was later supported by ${ }^{14} \mathrm{C}$ dating of organic soil layers interbedded with lake sediments near the town of Aksaray, which demonstrated a Last Glacial Maximum (LGM) highstand (Kashima 2002). At present, and probably throughout the Quaternary, the Tuz Gölü Basin has remained internally drained, as no paleochannels that may have drained the lake have been observed. Such a channel would have provided fluvial connectivity with the Kizilırmak River catchment and ultimately would have drained to the Black Sea. The Konya Basin, to the south of Tuz Gölü Lake, is also internally drained at present, but high lake levels during the LGM resulted in fluvial connectivity with the Tuz Gölü Basin (e.g., Roberts et al. 1999).

The sedimentary sequences showing evidence for the highest water levels of Tuz Gölü Lake consist of silt and sandstone with occasional beds of evaporites and sedimentary structures such as foresets and cross-bedding. These nearshore deposits are exposed at elevations of $\sim 1000 \mathrm{~m}$ in the vicinity of the present lake, and are covered by a veneer of caliche and gravel deposits that smooth the landscape, partly obscuring the remnants of shoreline geomorphic features. Near the town of Kulu, these nearshore deposits interfinger with rhythmic sequences of paleosoils and fluvial sediments. These units have been dated farther north, near Kömüşini, to between 0.4 and 0.7 Ma using electron spin resonance (Küçükuysal et al. 2011). Thus, the basin experienced multiple lake highstands and the earlier highstands might be of middle Pleistocene age.

\section{Methodology}

\subsection{Kinematic analysis}

Two different types of structural data were collected: (1) strike and dip measurements of bedding planes to determine the deformation styles; and (2) strike, dip, and slip-lineation measurements and kinematic indicators from fault planes to define the different deformation phases that occurred in the study area. A total of 106 dip-strike measurements of the bedding planes were recorded. Of these, 70 measurements were obtained from faults affecting the bedrock units and 36 were from faults affecting the cover units. For the analysis of the bedding planes, rose and contour diagrams were prepared using Dips v.5.1. Grooves, striations from abrasion during slip, elongated calcite fibers present in dilatational faults, and Riedel shears were used to infer the sense of movement on the fault planes. The relative ages of different sets of faults were established using cross-cutting relationships. Faultslip data analyses were processed using Angelier's direct inversion method v.5.42 (Angelier 1991). Vertical/subvertical stress axis and the value of the ratio $\phi$ were used to define the paleostress field (Angelier 1994). The range of stress fields include radial tension $\left(\sigma_{1}\right.$ vertical, $0<\phi<0.25$ ), pure tension ( $\sigma_{1}$ vertical, $\left.0.25<\phi<0.75\right)$, and transtension $\left(\sigma_{1}\right.$ vertical, $\left.0.75<\phi<1\right)$; strike-slip stress fields $\left(\sigma_{2}\right.$ vertical) with pure strike-slip ( $\sigma_{2}$ vertical, $\left.0.25<\phi<0.75\right)$, transtension $\left(\sigma_{2}\right.$ vertical, $\left.0.75<\phi<1\right)$, and transpression $\left(\sigma_{2}\right.$ vertical, $\left.0<\phi<0.25\right)$; and radial compression $\left(\sigma_{3}\right.$ vertical, $0.75<\phi<1)$, pure compression $\left(\sigma_{3}\right.$ vertical, $0.25<\phi<0.75)$, and transpression $\left(\sigma_{3}\right.$ vertical, $0<\phi<$ 0.25) (Delvaux et al. 1997). In order to calculate principal stress directions and to determine different deformational regimes, a total of 182 slip-data measurements were obtained from fault planes at 21 stations. A total of 136 slip-data measurements were previously published to characterize the recent activity of the Cihanbeyli and Yeniceoba fault zones (Özsayın \& Dirik 2007, 2011).

\section{2. ${ }^{40} \mathrm{Ar} /{ }^{39} \mathrm{Ar}$ dating}

Two ignimbrite levels are prominent in the stratigraphy of the Tuz Gölü Basin and accurate dating of those layers could provide useful constraints on the tectonostratigraphic history of the basin. We collected 2 samples from each layer for ${ }^{40} \mathrm{Ar} /{ }^{39} \mathrm{Ar}$ geochronology.

Fresh euhedral inclusion-free K-feldspar crystals (sanidine) were handpicked from ashes that were crushed and processed through the water table, magnetic, and heavy liquid mineral separation techniques. The grains were wrapped in commercial grade Al foil, and then packed in a $99.999 \%$ pure $\mathrm{Al}$ sample holder, which was wrapped in a $0.5-\mathrm{mm}$-thick $\mathrm{Cd}$ foil to shield the samples from the slow neutron flux. Irradiation was performed at the Geesthacht Neutron Facility of the GKSS research center of Geesthacht, Germany for $96 \mathrm{~h}$. The samples were irradiated together with the Fish Canyon Tuff sanidine standard to obtain the J value parameter describing the neutron flux. The sanidine standard was prepared at the Geological Survey of Japan and its determined age is 27.5 $\mathrm{Ma}$ (Uto et al. 1997; Ishizuka et al. 2002). $\mathrm{K}_{2} \mathrm{SO}_{4}$ and $\mathrm{CaF}_{2}$ crystals were also irradiated to correct for the interference of $\mathrm{Ar}$ isotopes produced by reactions of $\mathrm{K}$ or $\mathrm{Ca}$ in the samples. Additionally, 2 biotite K-Ar age standards, Sori93 biotite (92.6 \pm 0.6 Ma; Sudo et al. 1998) and HD-B1 biotite (24.21 $\pm 0.32 \mathrm{Ma}$; Hess \& Lippolt 1994), were also irradiated to confirm the accuracy of the J values through ${ }^{40} \mathrm{Ar} /{ }^{39} \mathrm{Ar}$ dating of those biotites. After irradiation, we extracted gas through a single total fusion procedure with a $50 \mathrm{~W} \mathrm{CO}_{2}$ New Wave Gantry Dual Wave laser ablation system (wavelength $10.6 \mu \mathrm{m}$ ). Sample grains were heated by a continuous $\mathrm{CO}_{2}$ laser beam with a diameter similar to the grain size for approximately $10 \mathrm{~s}$. Next, the released gas was purified with SAES Zr-Al alloy getters. Finally, the purified Ar gas was measured on an electron multiplier within a Micromass 5400 noble gas mass spectrometer with high sensitivity and ultralow background. The Ar isotopic ratios of each measurement were obtained after 
correcting for blank mass discrimination of atmospheric $\mathrm{Ar}$, interference of $\mathrm{Ar}$ isotopes derived from $\mathrm{Ca}$ and $\mathrm{K}$ during irradiation, and the decay of the radiogenic Ar isotopes $\left({ }^{37} \mathrm{Ar}\right.$ and $\left.{ }^{39} \mathrm{Ar}\right)$ produced by the irradiation. The calculation of ages and errors followed the procedure described by Uto et al. (1997). The error of the J value was estimated at $0.4 \%$. All errors in the text are reported at the 95\% $(2 \sigma)$ confidence interval.

\subsection{Interpretation of seismic reflection profiles}

Seismic reflection data obtained from the Tuz Gölü Basin in 1990 and 1991 by the Turkish Petroleum Corporation (TPAO) were provided to us by the General Directorate of Petroleum Affairs. The 2 seismic reflection sections, lines DG 2016 and KOV 90 617, correspond to lines C and D as interpreted by Fernández-Blanco et al. (this volume). We define 3 seismic-stratigraphic units (pre-Miocene, Late Miocene and Plio-Quaternary) combining the seismic units described by Fernández-Blanco et al. (this volume). The seismic reflection lines run NE-SW and are located at the southern margin of the present-day Tuz Gölü Lake. These lines partially overlap in the center of the basin, with line KOV 90617 shifted $5 \mathrm{~km}$ SE with respect to line DG 2016. Together, these sections cover a $100-\mathrm{km}$-long section that transects the main structures of the Tuz Gölü Basin, including the Sultanhanı Fault in the SW and the Tuz Gölü Fault Zone in the NE.

\subsection{Shoreline measurements}

At various sites surrounding the present-day lake, we identified geomorphic features characteristic of lacustrine shorelines formed during past lake highstands. We leveled topographic profiles across such shoreline features using a dual-frequency differential GPS (Leica 1200) at 10 sites surrounding the Tuz Gölü Lake, in an attempt to obtain offset data of the Tuz Gölü Fault. In addition, we sampled stromatolites associated with an erosive shoreline at Şereflikoçhisar Peninsula for radiocarbon dating.

\section{Results}

\subsection{Structural analysis}

\subsubsection{Attitude of bedding planes and folding}

Folds are one of the most distinctive structures for understanding the deformation of bedrock and cover units. We evaluated 2 generations of folding in the Tuz Gölü Basin. The first generation is pre-Upper Miocene in age and occurs at locations such as SW of the town of Yeniceoba and SE of the town of Şereflikoçhisar. The second generation of folding affects Pliocene limestones and younger clastic deposits. In general, throughout the region, the bedrock units are intensely folded and deformed while the Plio-Quaternary units are only gently folded.

In the western part of the Tuz Gölü Basin, bedrock units have beds that prominently strike between N50W and N60W, while in the eastern part of the basin, the strike of the bedding varies between N10W and N80W (Figures $3 a-3 b)$. On contour diagrams, the concentration of the poles to bedrock bedding planes on both sides of the basin shows a NE trend. According to the distribution of the poles, the average folding axis of the western part of the basin has a strike of $310^{\circ} \mathrm{N}$, while in the eastern part the average strike is $318^{\circ} \mathrm{N}$ (Figures $3 \mathrm{c}-3 \mathrm{~d}$ ). At the outcrop scale, these folds are related to thrust faults that juxtapose ophiolitic mélange units, Paleocene terrestrial clastics, and Eocene units with Oligo-Miocene clastic deposits and gypsum.

The bedding planes of the Plio-Quaternary units (except the Late Quaternary alluvial fan and talus deposits) are subhorizontal. Measurements taken closer to the faults show a slight tilting (Figures $4 \mathrm{a}-4 \mathrm{~b}$ ). While the predominant strike of Pliocene limestones ranges between N60W and N90W in the western part of the basin, the eastern part has a tighter clustering between N80W and N90W (Figures 5a-5b). The Plio-Quaternary units commonly show open folding on both sides of the basin. The distribution of poles to the bedding planes has an approximate $\mathrm{N}-\mathrm{S}$ trend. The average folding axis for the western part of the basin has a strike of $273^{\circ} \mathrm{N}$, while the eastern part has an average strike of $280^{\circ} \mathrm{N}$ (Figures $5 \mathrm{c}-5 \mathrm{~d})$. Open folding observed on the Pliocene limestones is associated with normal faults located in the central part of the Cihanbeyli Fault Zone.

\subsubsection{Faults}

The major fault zones that have influenced the PlioQuaternary evolution of the Tuz Gölü Basin include the Yeniceoba, Cihanbeyli, Sultanhanı, and Tuz Gölü fault zones.

The 130-km-long Yeniceoba Fault Zone is exposed between the towns of Günyüzü and Yeniceoba (Figure 1b). It is the middle branch of the İnönü-Eskişehir Fault System fanning out at Sivrihisar. The general strike of the fault zone varies between N50W and N60W. Its morphological characteristics include linear valleys, fault scarps, and linear alignments of alluvial fans south of Yeniceoba. A fault plane with 2 superimposed sets of slickenlines indicates a 2 -stage deformational history (Figures 6a-6c). While a first set of slickenlines points to pure dextral strike-slip faulting, the superimposed set records normal faulting with a dextral component. This fault zone juxtaposes the bedrock units (Ophiolitic mélange units, Paleocene terrestrial clastics, Eocene limestones, and Oligo-Miocene clastics) against Pliocene limestones in several locations.

The 80-km-long Cihanbeyli Fault Zone, which forms the southern branch of the fanning İnönü-Eskişehir Fault System, strikes N55W and is located between the towns of Sülüklü and Cihanbeyli (Figure 1b). At the central and western parts, the fault zone has SE-dipping fault planes, 


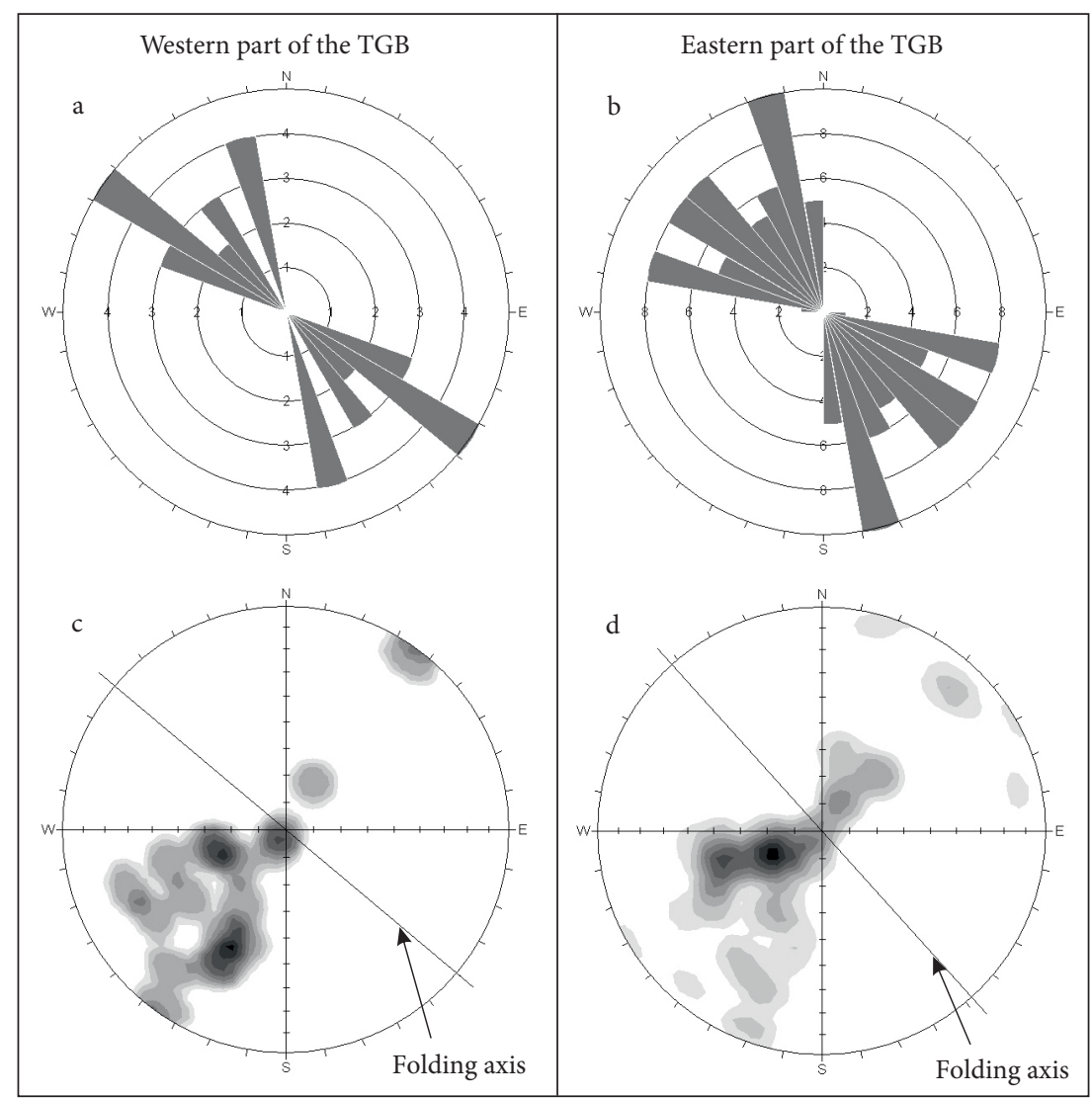

Figure 3. Rose diagrams showing strike measurements taken from bedding planes of bedrock units cropping out at (a) the western part of the Tuz Gölü Basin ( $\mathrm{n}=18)$, and (b) the eastern part of the basin $(n=56)$. Also, stereographic contoured plot of the poles to the bedding planes measured from bedrock units cropping out at (c) the western part of the basin $(\mathrm{n}=18)$ manifesting an asymmetrical folding with a strike of $310^{\circ} \mathrm{N}$, and $(\mathrm{d})$ the eastern part of the basin $(n=56)$ manifesting an asymmetrical folding with a strike of $318^{\circ} \mathrm{N}$.

while at the eastern part, the faults have both NE- and SEdipping surfaces that delimit the $\sim 400$-m-wide and 15-kmlong Cihanbeyli Graben, which is filled with Quaternary deposits (Figures $4 \mathrm{a}$ and $6 \mathrm{~d}$ ). Fault scarps, triangular facets, alluvial fans, and linear alignment of springs are prominent morphological features of this fault zone that attest to its neotectonic character.

The 70-km-long Sultanhanı Fault Zone, which constitutes the SE part of the İnönü-Eskişehir Fault, is situated between the towns of Cihanbeyli and Sultanhanı (Figure 1b). Although there are no fault plane measurements from the Sultanhanı Fault Zone, normal to strike-slip faults were identified on seismic profiles (Kutluay et al. 2010, Fernández-Blanco et al. this volume).

The 135-km-long Tuz Gölü Fault Zone, with its N30$40 \mathrm{~W}$ strike and SW- and NE-dipping fault planes, is one of the most important fault zones in Central Anatolia. It stretches from the town of Kulu to Hasandağ Volcano. Its fault segments constitute the eastern boundary of Tuz Gölü Lake. The Tuz Gölü Fault Zone juxtaposes the bedrock units against Plio-Quaternary sediments and cuts Pliocene limestones and recent alluvium (Figures $7 \mathrm{a}-7 \mathrm{c}$ ). Fault scarps, alluvial fans, linear valleys, and linearly aligned parasitic cones around Hasandağ Volcano are the morphological features of this fault zone. Southeast of Şereflikoçhisar, a fault plane having a N35W strike with superimposed slickenlines was also observed. The older set of faults shows dextral strike-slip faulting with a minor reverse component, whereas the superimposed slickenlines show normal faulting with a dextral strike-slip component. This situation is similar to that observed in the Yeniceoba Fault Zone. 


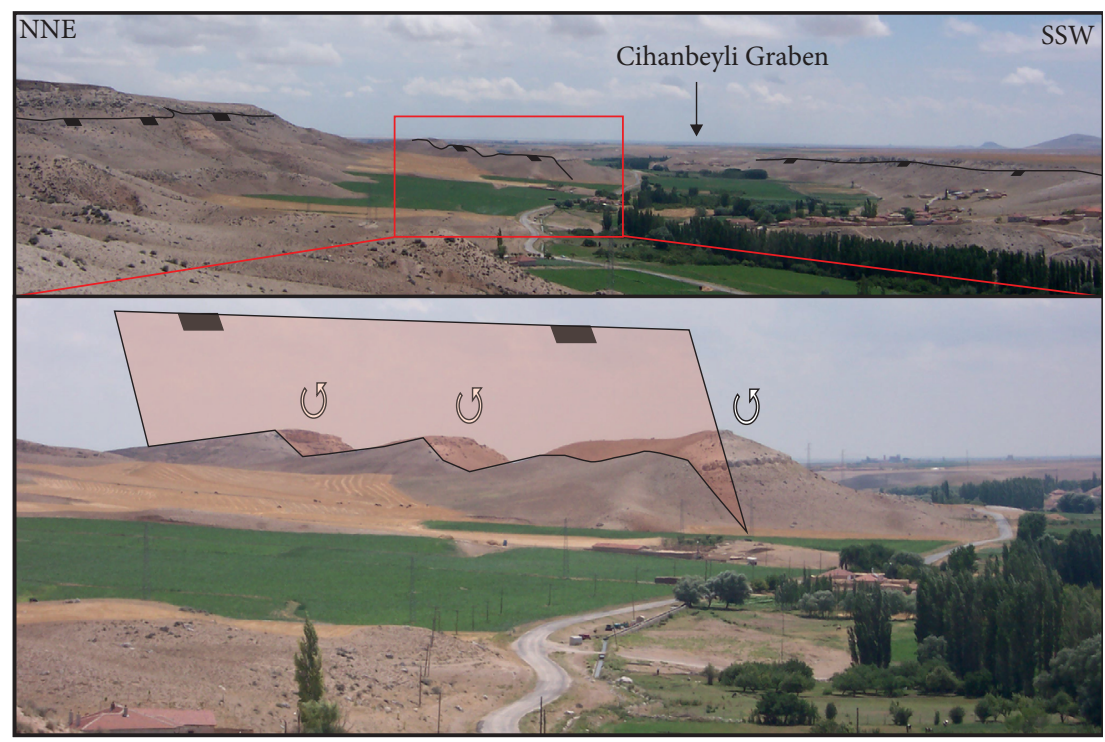

Figure 4. Photos showing (a) the tilting of Pliocene limestones due to normal faults in the Cihanbeyli Graben, and (b) a close-up view of the tilting.

\subsubsection{Kinematic analysis}

To describe the characteristics and timing of the neotectonic deformational phases that affected the study area, we took into account all faults that cut both bedrock and cover units. We separated the data into 2 sets: the first is from faults that affect only the bedrock units, and the second is from faults that affect cover units. Field observations of macro- and mesoscale faults and paleostress analyses show 2 deformation phases that affected the bedrock units, but only a single phase of deformation that affected the cover units.

The first data set on faults that affect the bedrock units shows 2 deformation regimes. The first is a shortening regime with a compressional axis directed NNW-SSE to NE-SW. At stations 4 and 16, $\sigma_{3}$ is vertical, and $\phi$ values imply pure compression (Figure 8 and Table 1). In the field, the macroscale deformation observed at these locations is characterized by thrust and backthrust faults of ophiolitic mélange and Eocene units onto Oligo-Miocene units and onto each other. At station 3, a fault plane that separates the Oligo-Miocene clastics from the Pliocene limestones has superimposed slickenlines. While the first movement on the footwall (Oligo-Miocene clastics) is dextral strikeslip in response to a N-S compressional stress regime (3$1 ; \sigma_{2}$ vertical and $\phi$ values imply a strike-slip stress field), the superposed slickenlines record normal faulting with a dextral strike-slip component (on both hanging and footwalls) (Figure 8 and Table 1). Another reactivated fault plane was also observed at station 15 (15-1). In the first stage of deformation, this plane shows dextral strikeslip faulting with a minor reverse component, whereas the superposed slickenlines indicate pure dip-slip (normal) motion (Figure 8 and Table 1).

The second data set from kinematic indicators on faults that affect the cover units is characterized by a single NNE-SSW to NE-SW tensional stress regime. At stations $1,2,3-2,5,9,10,12,14$, and $17, \sigma_{1}$ is vertical and $\phi$ values indicate a pure tensional stress regime, whereas stations 6 , $7,8,11,13,15-2,18$, and 19 show radial tensions according to the same criteria (Figure 8 and Table 1). Macroscale deformation pertaining to this stress regime is primarily characterized by pure normal faults and normal faults with a minor strike-slip component that cut Pliocene and Quaternary units (Figure 8 and Table 1).

\section{2. ${ }^{40} \mathrm{Ar} /{ }^{39} \mathrm{Ar}$ dating}

We sampled the lower, pinkish-white ignimbrite level in the Tuz Gölü Basin, which caps the basement rocks with an angular unconformity (Figure 2), in 2 locations: $38^{\circ} 40.290^{\prime} \mathrm{N}, 33^{\circ} 46.487^{\prime} \mathrm{E}$ (sample BR-1) and $38^{\circ} 40.018^{\prime} \mathrm{N}$, $33^{\circ} 46.774^{\prime} \mathrm{E}$ (sample BR-2). The upper, whitish ignimbrite level, which underlies the Pliocene limestones (Fig. 2), was sampled in two locations: $38^{\circ} 47.871^{\prime} \mathrm{N}, 34^{\circ} 07.902^{\prime} \mathrm{E}$ (sample 08VAMP01) and $38^{\circ} 36.165^{\prime} \mathrm{N}, \quad 33^{\circ} 53.234^{\prime} \mathrm{E}$ (sample 08VAMP02) (Figure 8). The results of individual high-potassium feldspar grain analyses for the 4 analyzed samples are provided in Table 2.

From the lower ignimbrite layer, 8 high-potassium feldspar grains from sample BR-1 form a tight cluster of ages that result in a weighted mean ${ }^{40} \mathrm{Ar} /{ }^{39} \mathrm{Ar}$ date of 6.51 $\pm 0.34 \mathrm{Ma}(\mathrm{MSWD}=0.47)$. Similarly, 8 high-potassium feldspar grains from sample BR-2 result in a weighted mean ${ }^{40} \mathrm{Ar} /{ }^{39} \mathrm{Ar}$ date of $7.14 \pm 0.36 \mathrm{Ma}(\mathrm{MSWD}=0.70)$. 


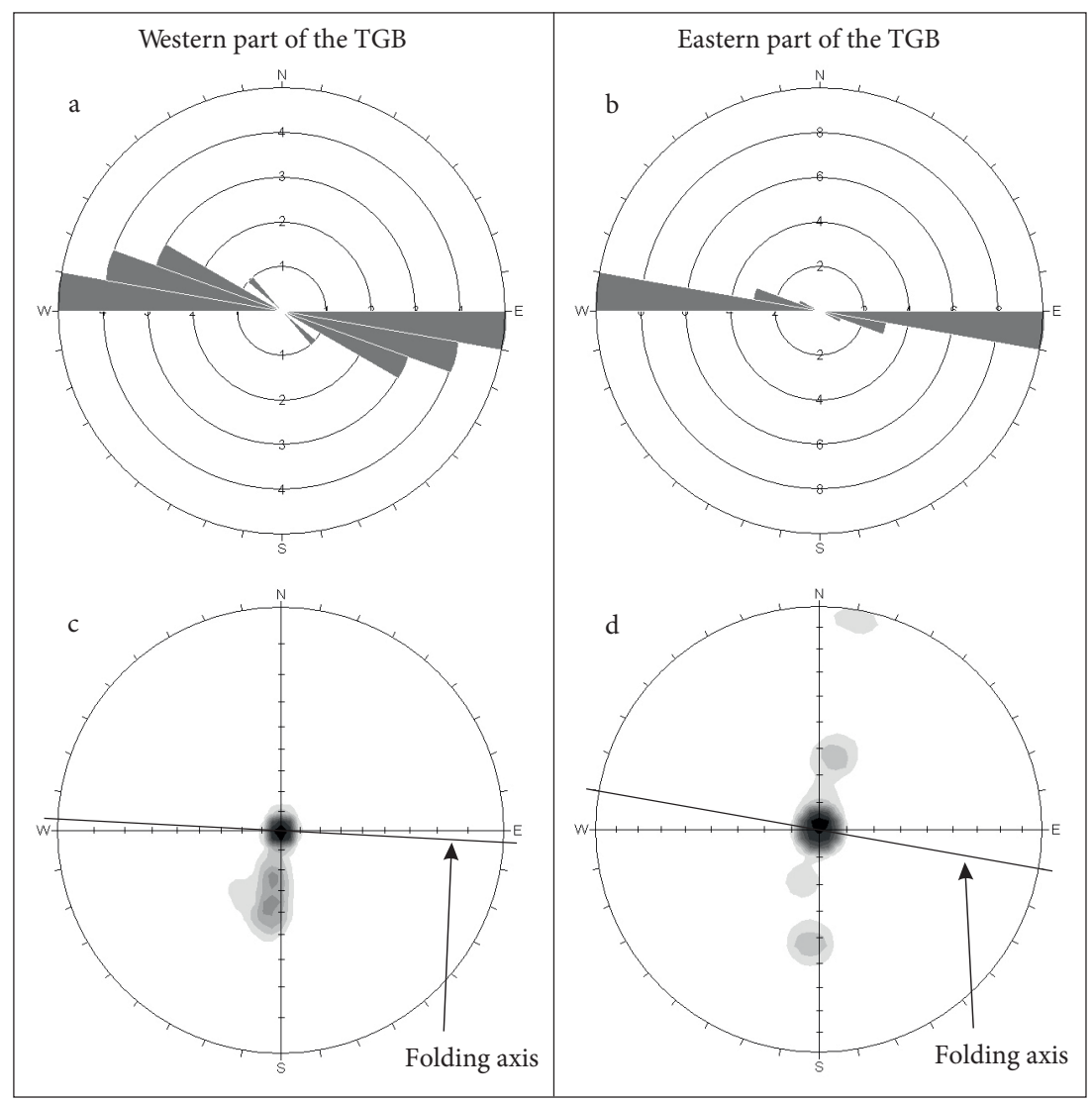

Figure 5. Rose diagrams showing strike measurements taken from bedding planes of cover units cropping out at (a) the western part of the Tuz Gölü Basin ( $n=18)$, and (b) the eastern part of the basin $(n=14)$. Also, stereographic contoured plot of the poles to the bedding planes measured from bedrock units cropping out at (c) the western part of the basin ( $\mathrm{n}=$ 18) manifesting an asymmetrical folding with a strike of $273^{\circ} \mathrm{N}$, and (d) the eastern part of the basin $(\mathrm{n}=14)$ manifesting an asymmetrical folding with a strike of $280^{\circ} \mathrm{N}$.

If the samples were indeed derived from the same unit, as we suppose, all 16 grains result in a weighted mean date of $6.81 \pm 0.24 \mathrm{Ma}(\mathrm{MSWD}=0.98)$.

From the younger upper ignimbrite layer that underlies the Pliocene limestones, 7 out of the 8 high-potassium feldspar grains analyzed from sample 08VAMP01 form a tight cluster, while 1 older grain (possibly from a reworked source) was excluded from the age calculation. The 7 clustered grains result in a weighted mean ${ }^{40} \mathrm{Ar} /{ }^{39} \mathrm{Ar}$ date of $5.23 \pm 0.36 \mathrm{Ma}(\mathrm{MSWD}=0.67)$. Furthermore, 8 high-potassium feldspar grains analyzed from sample 08VAMP02 form a tight cluster that results in a weighted mean ${ }^{40} \mathrm{Ar} /{ }^{39} \mathrm{Ar}$ date of $4.96 \pm 0.24 \mathrm{Ma}(\mathrm{MSWD}=0.53)$. Assuming all 15 grains are from the same ignimbrite, they result in a weighted mean date of $5.02 \pm 0.20 \mathrm{Ma}(2 \sigma$ error, MSWD $=0.66$ ).

\subsection{Interpretation of seismic reflection profiles}

The seismic reflection lines reveal variations in the thickness of sedimentary units and the geometry of faults within the Tuz Gölü Basin in a NE-SW direction (Figures 8 and 9). The Tuz Gölü Fault and the Sultanhanı Fault are the major faults imaged by the seismic lines. The boundary between Unit 1 (Plio-Quaternary) and Unit 2 (Upper Miocene) is poorly constrained due to the low quality of the seismic lines and the absence of reflections in the upper $0.2-0.4 \mathrm{~s}$. This boundary is instead defined by differences in seismic velocities and lithology found in well TG6 (details in Fernández-Blanco et al. this volume), located at the SE end of line DG 2016 (Figure 9).

We observe thickening of Unit 1 (Plio-Quaternary) in association with the Tuz Gölü Fault, but not with the Sultanhanı Fault. In contrast, the thickness of Unit 2 (Upper Miocene), which is better constrained, increases in relation to both the Sultanhanı and the Tuz Gölü faults (Figure 9). One exception occurs NE of the Tuz Gölü Fault, where thickening of the Neogene units is not seen. At a deeper position, a prominent angular unconformity separates Unit 2 (Upper Miocene) from Unit 3 (pre-Upper Miocene). 

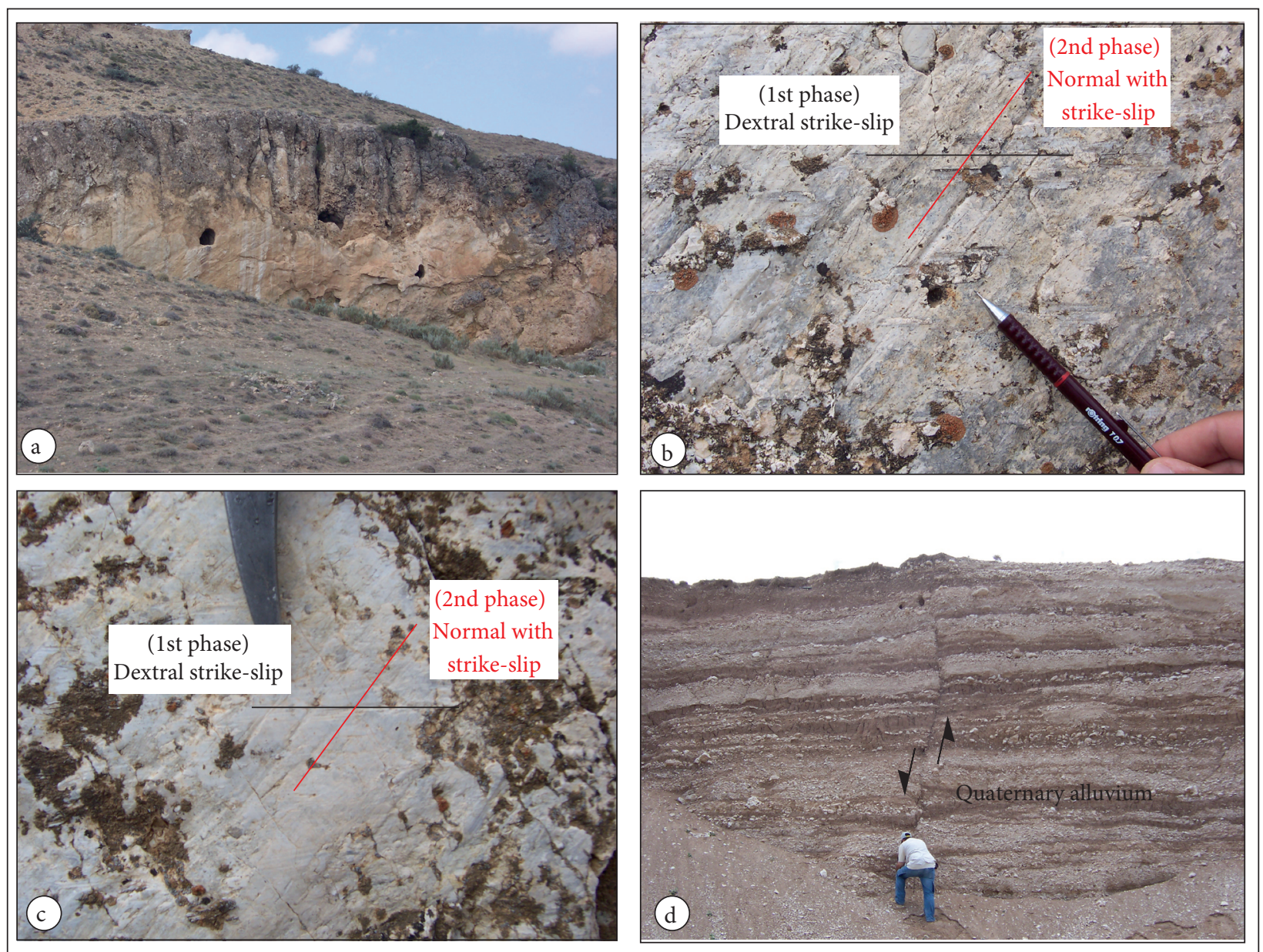

Figure 6. Photos showing (a) the fault plane with superimposed sets of slickenlines on the Yeniceoba Fault Zone, (b) a close-up view of superposed slickenlines, (c) the Cihanbeyli Graben, and (d) Quaternary alluvium cut by NE-dipping fault plane of the Cihanbeyli Fault Zone.

In the western line, the Sultanhanı Fault consists of 2 extensional SW-dipping faults involving basement (profile DG 2016 in Figure 9). These faults and the relatively minor adjacent faults do not offset Unit 1 (Plio-Quaternary). However, they clearly offset Unit 2 (Upper Miocene), and are associated with an increased thickness of some 200$300 \mathrm{~m}$ in line DG 2016 (Figure 9). On this line, a similar type of relationship is seen for associated structures NE of the Sultanhanı Fault.

The Tuz Gölü Fault Zone is a complex system of SWand NE-dipping faults. The most prominent member is the Tuz Gölü Fault, which is a SW-dipping fault associated with several other minor structures (line KOV 90617 in Figure 9). Toward the SW, in the hanging wall of the Tuz Gölü Fault, numerous secondary (predominantly extensional) faults create a diffuse deformation zone, with associated subsidence allowing for the deposition of thick strata of Upper Miocene units. The increase in thickness of Unit 2 (Upper Miocene) in relation to the Tuz Gölü Fault is more than $500 \mathrm{~m}$. Farther to the SW, 2 other faults are parallel to the Tuz Gölü Fault, and these correspond to the SE continuation of the faults observed at both margins of the peninsula.

In both lines, Units 1 and 2 can be clearly observed on both hanging and footwall blocks of the Sultanhanı and Tuz Gölü fault zones. This is an important indication that these fault zones have not controlled the limits of the Tuz Gölü Basin and have rather acted as intrabasinal fault systems.

\subsection{Late Pleistocene shorelines of the Tuz Gölü Lake}

\subsubsection{Geomorphology and ages of shoreline features}

Geomorphic features associated with past lake shorelines were found at various sites surrounding the modern Tuz Gölü Lake at elevations between 930 and 970 m, except at 

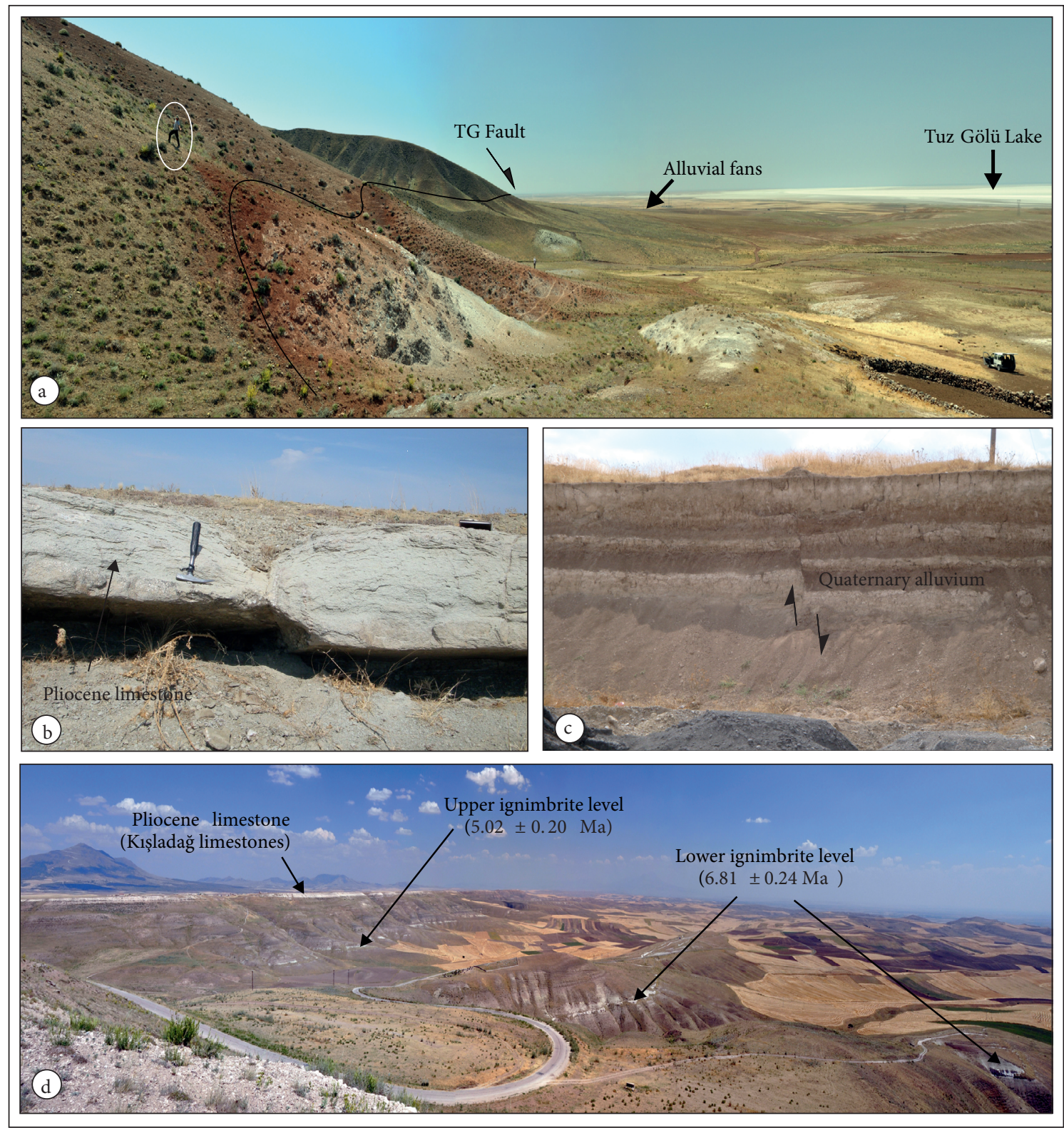

Figure 7. Photos showing (a) the main strand of the Tuz Gölü Fault Zone, (b) Pliocene limestones cut by a minor fault of the Tuz Gölü Fault Zone, (c) Quaternary alluvium cut by the Tuz Gölü Fault Zone, and (d) the upper ignimbrite level and Pliocene limestones.

the peninsula site west of Şereflikoçhisar ("Şereflikoçhisar Peninsula"), where the paleoshoreline reaches up to 1015 $\mathrm{m}$ (Figures 8 and 10). These isolated shorelines are not considered continuous when compared, for example, with shorelines found along the adjacent Konya Basin (Naruse et al. 1997), or those associated with the late PleistoceneHolocene lakes of the East African Rift formed in a similar arid climate (Garcin et al. 2009, 2012; Melnick et al. 2012). The shoreline features surrounding the Tuz Gölü Basin consist of wave-cut notches, abrasion platforms, regressive ridges with beach gravels, and bedrock cliffs. These features have been carved into resistant sedimentary and volcanic Tertiary bedrock as well as into Quaternary volcanics of the Hasandağ volcano south of Aksaray.

At the peninsula site, we obtained a radiocarbon age from a stromatolitic crust of $21.8 \pm 0.4$ calendar kiloyears before the present (cal. kyr BP) (Figures 8 and 10, Table 3 ), consistent with a lake highstand during the LGM. Radiocarbon ages as old as $22.4 \mathrm{cal}$. kyr BP have been obtained from lake sediments near Aksaray (Kashima 


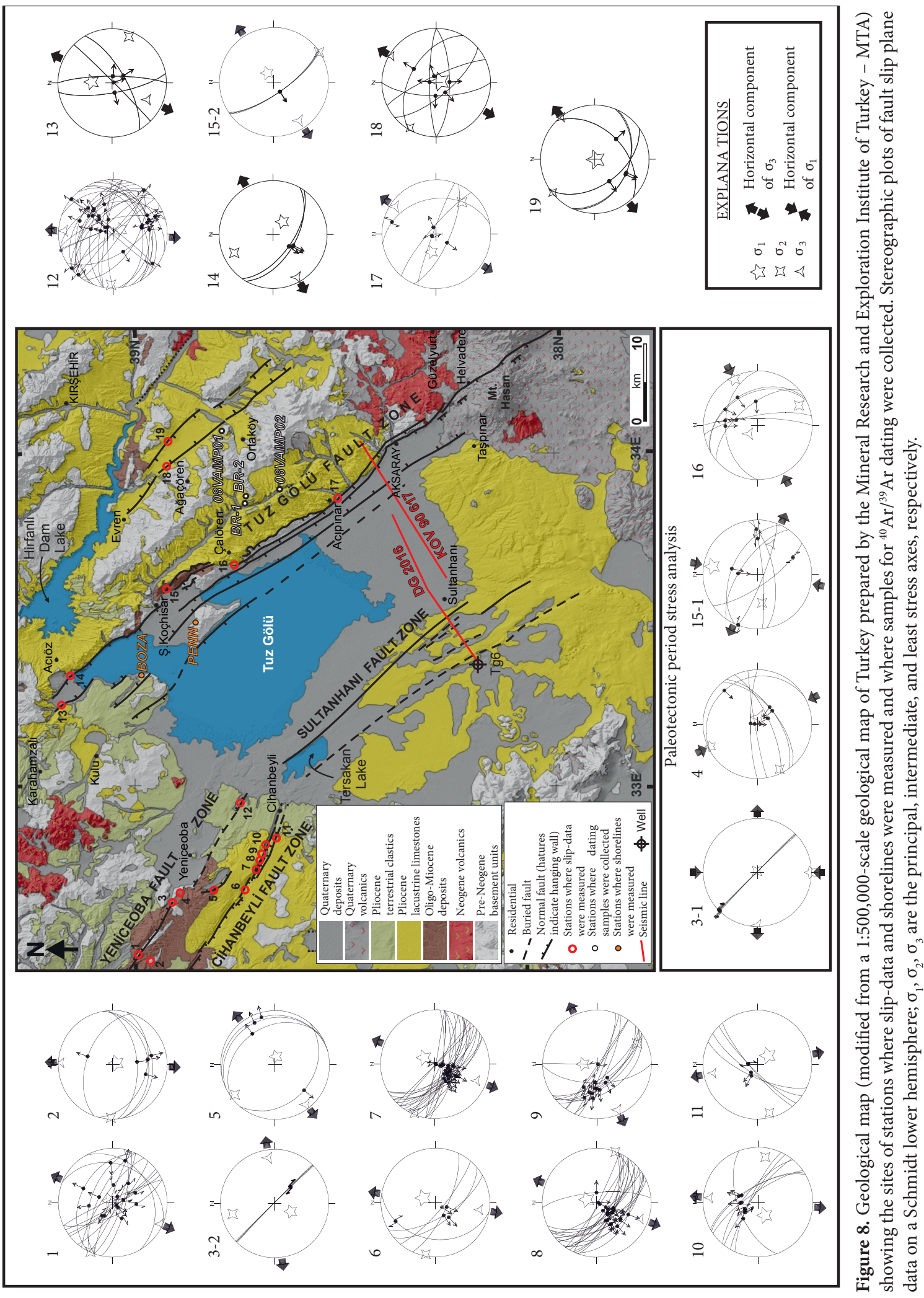


Table 1. Field information and kinematic analysis results of slip-data measurements.

\begin{tabular}{|c|c|c|c|c|c|c|c|}
\hline Station no. & Easting & Northing & \# of slip-data & $\begin{array}{l}\text { Stress } \\
\text { axis }\end{array}$ & $\phi$ & Explanation & Stress regime \\
\hline 1 & 454535 & 4317437 & 16 & $\begin{array}{c}\sigma_{1}=030^{\circ} / 85^{\circ} \\
\sigma_{2}=294^{\circ} / 1^{\circ} \\
\sigma_{3}=204^{\circ} / 5^{\circ}\end{array}$ & 0.337 & $\begin{array}{l}\text { Ophiolitic mélange- } \\
\text { Pliocene limestone } \\
\text { boundary }\end{array}$ & \\
\hline 2 & 452110 & 4314142 & 5 & $\begin{array}{l}\sigma_{1}=156^{\circ} / 84^{\circ} \\
\sigma_{2}=272^{\circ} / 3^{\circ} \\
\sigma_{3}=002^{\circ} / 5^{\circ}\end{array}$ & 0.261 & Pliocene limestones & \\
\hline $3-1$ & 470340 & 4306800 & 1 & $\begin{array}{l}\sigma_{1}=180^{\circ} / 1^{\circ} \\
\sigma_{2}=071^{\circ} / 88^{\circ} \\
\sigma_{3}=270^{\circ} / 2^{\circ}\end{array}$ & 0.522 & $\begin{array}{l}\text { Oligo-Miocene clastics } \\
\text { / Pliocene limestones } \\
\text { boundary }\end{array}$ & \\
\hline $3-2$ & 470340 & 4306800 & 1 & $\begin{array}{l}\sigma_{1}=206^{\circ} / 63^{\circ} \\
\sigma_{2}=346^{\circ} / 22^{\circ} \\
\sigma_{3}=082^{\circ} / 16^{\circ}\end{array}$ & 0.422 & $\begin{array}{l}\text { Oligo-Miocene clastics } \\
\text { / Pliocene limestones } \\
\text { boundary }\end{array}$ & \\
\hline 4 & 472729 & 4304637 & 6 & $\begin{array}{l}\sigma_{1}=335^{\circ} / 6^{\circ} \\
\sigma_{2}=244^{\circ} / 8^{\circ} \\
\sigma_{3}=099^{\circ} / 80^{\circ}\end{array}$ & 0.740 & $\begin{array}{l}\text { Ophiolitic mélange- } \\
\text { Eocene limestone } \\
\text { boundary }\end{array}$ & \\
\hline 5 & 483816 & 4282654 & 8 & $\begin{array}{l}\sigma_{1}=242^{\circ} / 68^{\circ} \\
\sigma_{2}=099^{\circ} / 18^{\circ} \\
\sigma_{3}=005^{\circ} / 12^{\circ}\end{array}$ & 0.273 & $\begin{array}{l}\text { Quaternary talus and } \\
\text { alluvial fan }\end{array}$ & \\
\hline 6 & 470147 & 4291124 & 5 & $\begin{array}{l}\sigma_{1}=021^{\circ} / 71^{\circ} \\
\sigma_{2}=280^{\circ} / 4^{\circ} \\
\sigma_{3}=189^{\circ} / 19^{\circ}\end{array}$ & 0.229 & Pliocene limestones & \\
\hline 7 & 474388 & 4287855 & 22 & $\begin{array}{l}\sigma_{1}=031^{\circ} / 71^{\circ} \\
\sigma_{2}=293^{\circ} / 3^{\circ} \\
\sigma_{3}=202^{\circ} / 19^{\circ}\end{array}$ & 0.167 & Pliocene limestones & \\
\hline 8 & 478629 & 4285420 & 21 & $\begin{array}{l}\sigma_{1}=017^{\circ} / 75^{\circ} \\
\sigma_{2}=110^{\circ} / 1^{\circ} \\
\sigma_{3}=200^{\circ} / 15^{\circ}\end{array}$ & 0.233 & Pliocene limestones & \\
\hline 9 & 479757 & 4284687 & 12 & $\begin{array}{l}\sigma_{1}=001^{\circ} / 69^{\circ} \\
\sigma_{2}=153^{\circ} / 18^{\circ} \\
\sigma_{3}=246^{\circ} / 9^{\circ}\end{array}$ & 0.390 & Pliocene limestones & \\
\hline
\end{tabular}


Table 1. (continued).

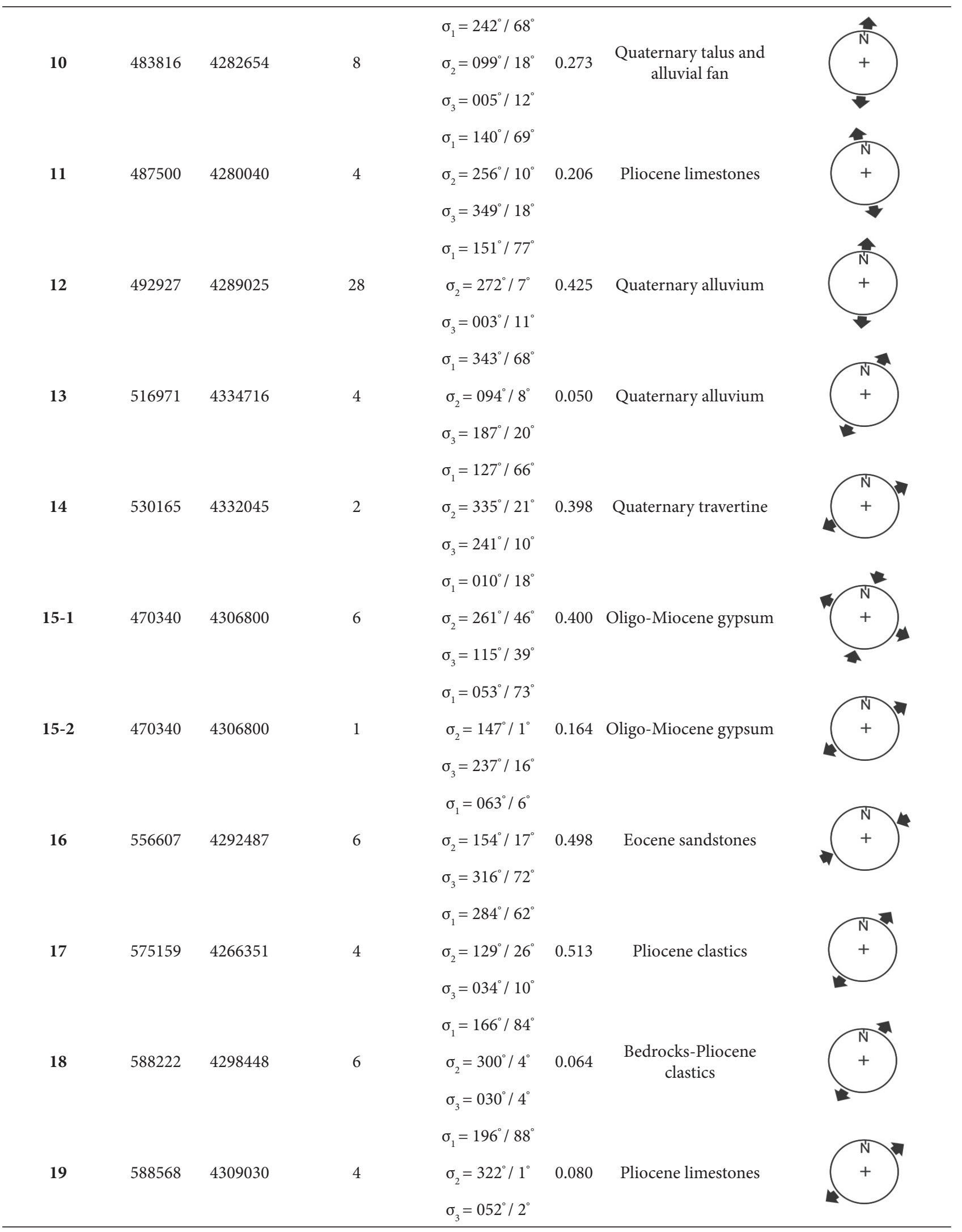


ÖZSAYIN et al. / Turkish J Earth Sci

Table 2. Analytical results of single grain total-fusion ${ }^{40} \mathrm{Ar} /{ }^{39} \mathrm{Ar}$ analyses.

\begin{tabular}{|c|c|c|c|c|c|c|c|c|c|c|c|c|c|c|c|c|c|}
\hline Laser output & \multicolumn{3}{|c|}{${ }^{40} \mathrm{Ar} /{ }^{39} \mathrm{Ar}$} & \multicolumn{3}{|c|}{${ }^{37} \mathrm{Ar} /{ }^{39} \mathrm{Ar}$} & \multicolumn{3}{|c|}{$\begin{array}{c}{ }^{36} \mathrm{Ar} /{ }^{39} \mathrm{Ar} \\
\left(\mathrm{x} 10^{-3}\right)\end{array}$} & $\mathrm{K} / \mathrm{Ca}$ & $\begin{array}{c}{ }^{40} \mathrm{Ar}^{\star} \\
(\%)\end{array}$ & \multicolumn{3}{|c|}{${ }^{40} \mathrm{Ar}^{\star} /{ }^{39} \mathrm{Ar}_{\mathrm{K}}$} & \multicolumn{3}{|c|}{$\begin{array}{l}\operatorname{Age}( \pm 1 \mathrm{~s}) \\
(\mathrm{Ma})\end{array}$} \\
\hline \multicolumn{2}{|c|}{$\begin{array}{c}\text { Sample ID: } \\
\text { BR-1-SA }\end{array}$} & \multicolumn{4}{|c|}{ Lab ID: C10021 } & \multicolumn{4}{|c|}{ Neutron irradiation: GeNF } & & & & & & & & \\
\hline $\mathrm{J}=$ & \multicolumn{3}{|c|}{0.002053} & & & & & & & & & & & & & & \\
\hline $4.80 \%$ & 2.94 & \pm & 0.03 & 4.58 & \pm & 1.15 & 5.56 & \pm & 0.46 & 0.13 & 63.46 & 1.88 & \pm & 0.20 & 6.93 & \pm & 0.73 \\
\hline $4.80 \%$ & 3.63 & \pm & 0.01 & 3.76 & \pm & 0.58 & 7.59 & \pm & 0.21 & 0.16 & 51.10 & 1.86 & \pm & 0.10 & 6.89 & \pm & 0.35 \\
\hline $4.80 \%$ & 5.17 & \pm & 0.01 & 2.47 & \pm & 0.81 & 12.62 & \pm & 0.23 & 0.24 & 33.76 & 1.75 & \pm & 0.12 & 6.46 & \pm & 0.45 \\
\hline $4.80 \%$ & 4.24 & \pm & 0.02 & 1.64 & \pm & 0.55 & 9.11 & \pm & 0.25 & 0.36 & 41.31 & 1.76 & \pm & 0.10 & 6.49 & \pm & 0.37 \\
\hline $4.80 \%$ & 3.95 & \pm & 0.03 & 3.55 & \pm & 0.74 & 9.49 & \pm & 0.31 & 0.17 & 40.21 & 1.59 & \pm & 0.13 & 5.90 & \pm & 0.49 \\
\hline $4.80 \%$ & 7.33 & \pm & 0.04 & 3.18 & \pm & 1.04 & 20.12 & \pm & 0.31 & 0.18 & 24.28 & 1.78 & \pm & 0.16 & 6.60 & \pm & 0.59 \\
\hline $4.80 \%$ & 4.26 & \pm & 0.04 & 3.41 & \pm & 0.77 & 10.11 & \pm & 0.34 & 0.17 & 39.76 & 1.70 & \pm & 0.14 & 6.28 & \pm & 0.52 \\
\hline \multirow[t]{2}{*}{$4.80 \%$} & 3.99 & \pm & 0.02 & 4.42 & \pm & 1.40 & 9.51 & \pm & 0.43 & 0.13 & 43.27 & 1.73 & \pm & 0.22 & 6.41 & \pm & 0.80 \\
\hline & & & & & & & & & & \multicolumn{5}{|c|}{ Weighted average of all ages: } & 6.51 & \pm & 0.17 \\
\hline Laser output & & 17 & & ${ }^{37} \mathrm{Ar} /{ }^{3}$ & & & $\begin{array}{l}{ }^{36} \mathrm{Ar} /{ }^{39} \\
\left(\mathrm{x} 10^{-}\right.\end{array}$ & & & $\mathrm{K} / \mathrm{Ca}$ & $\begin{array}{c}{ }^{40} \mathrm{Ar}^{\star} \\
(\%)\end{array}$ & & & & & $\mathrm{Ma})$ & \\
\hline
\end{tabular}

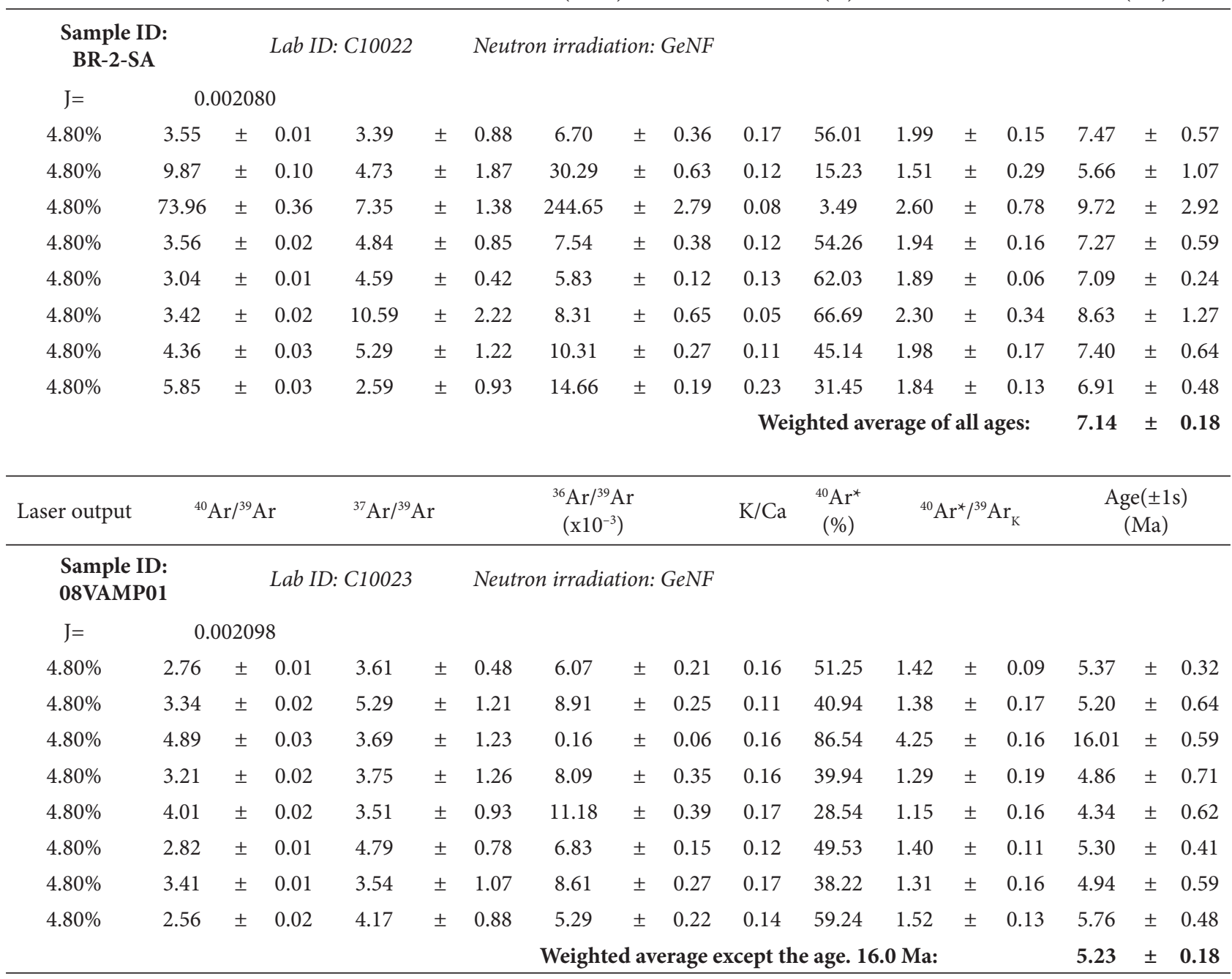


Table 2. (continued).

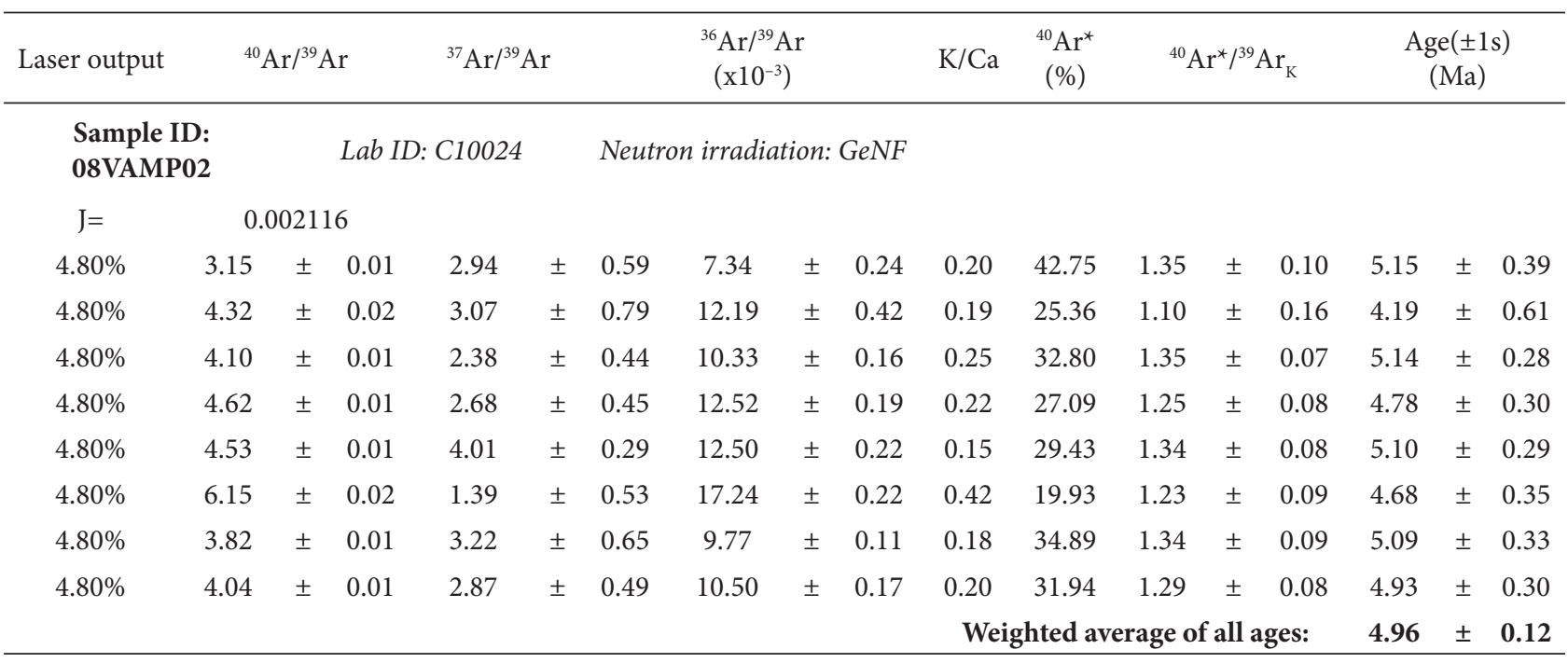

$100 \%$ laser output corresponds to 50W. K/Ca ratios are estimated with the production rates for K-derived ${ }^{39} \mathrm{Ar}$ and $\mathrm{Ca}$-derived $37 \mathrm{Ar}$ summarized in McDougall \& Harrison (1999). ${ }^{40} \mathrm{Ar}^{*}=$ radiogenic ${ }^{40} \mathrm{Ar}$.

2002), and ${ }^{14} \mathrm{C}, \mathrm{U} / \mathrm{Th}$, and luminescence ages that cluster around the LGM have been acquired from the adjacent Konya Basin (e.g., Roberts et al. 1999). This lake highstand is evidence for a wet climate during the LGM in central Anatolia and is consistent with the cosmogenic nuclide ages of glacial moraines in the nearby Taurus Mountains and Erciyes Volcano as well as the results of climate modeling (e.g., Sarıkaya et al. 2008, 2009; Zreda et al. 2011).

\subsubsection{Distribution of Pleistocene shorelines}

The geomorphic expression of past highstand shorelines depends on the duration and stability of the lake level as well as on regional erosive and depositional processes and their respective rates (e.g., Garcin et al. 2012; Melnick et al. 2012). The presence of an overflow sill ensuring fluvial connectivity of the lacustrine basin would result in protracted water level positions during wet climate conditions. In contrast, if water levels were not high enough to reach an overflow elevation and internal drainage conditions also prevailed during the highstand, the water level would not remain stable and would be controlled by transient short-period oscillations. Such variations might have a high frequency and amplitude, as suggested by decadal lake-level changes for endorheic lakes on the order of $\sim 10 \mathrm{~m}$ at Lake Turkana in East Africa (Butzer 1971), and up to $\sim 4 \mathrm{~m}$ at Lake Van in Turkey (DSİ 1998; Kuzucuoğlu et al. 2010). Thus, under protracted endorheic conditions, the formation of distinct shoreline erosive features could be reduced or even inhibited depending on bedrock erodibility, wave and wind regimes, and the amplitude and frequency of short-period water-level variations.

Because the Tuz Gölü Basin apparently remained internally drained during the LGM highstand and possibly also during previous phases of high water levels, erosive highstand shorelines developed only locally and with limited geomorphic expression and spatial continuity. Thus, the geomorphic correlation of shorelines among sites is tenuous and should be supported by independent age determinations. In addition, a pronounced phase of alluvial fan development further affected the region

Table 3. Radiocarbon age of the stromatolite crust from the Tuz Gölü highstand shoreline, Şereflikoçhisar Peninsula (see Figure 10 for location).

\begin{tabular}{|c|c|c|c|c|}
\hline Lab ID & Conventional Age & $d^{13} \mathrm{C}(\%)$ & Cal years BP & $2 s$ error \\
\hline KIA39874 & $18,210 \pm 100 \mathrm{BP}$ & $-5.24 \pm 0.29$ & 21781.5 & 362.5 \\
\hline
\end{tabular}

*calibrated with OxCal 4.1 and IntCal09 (Reimer et al. 2009) 


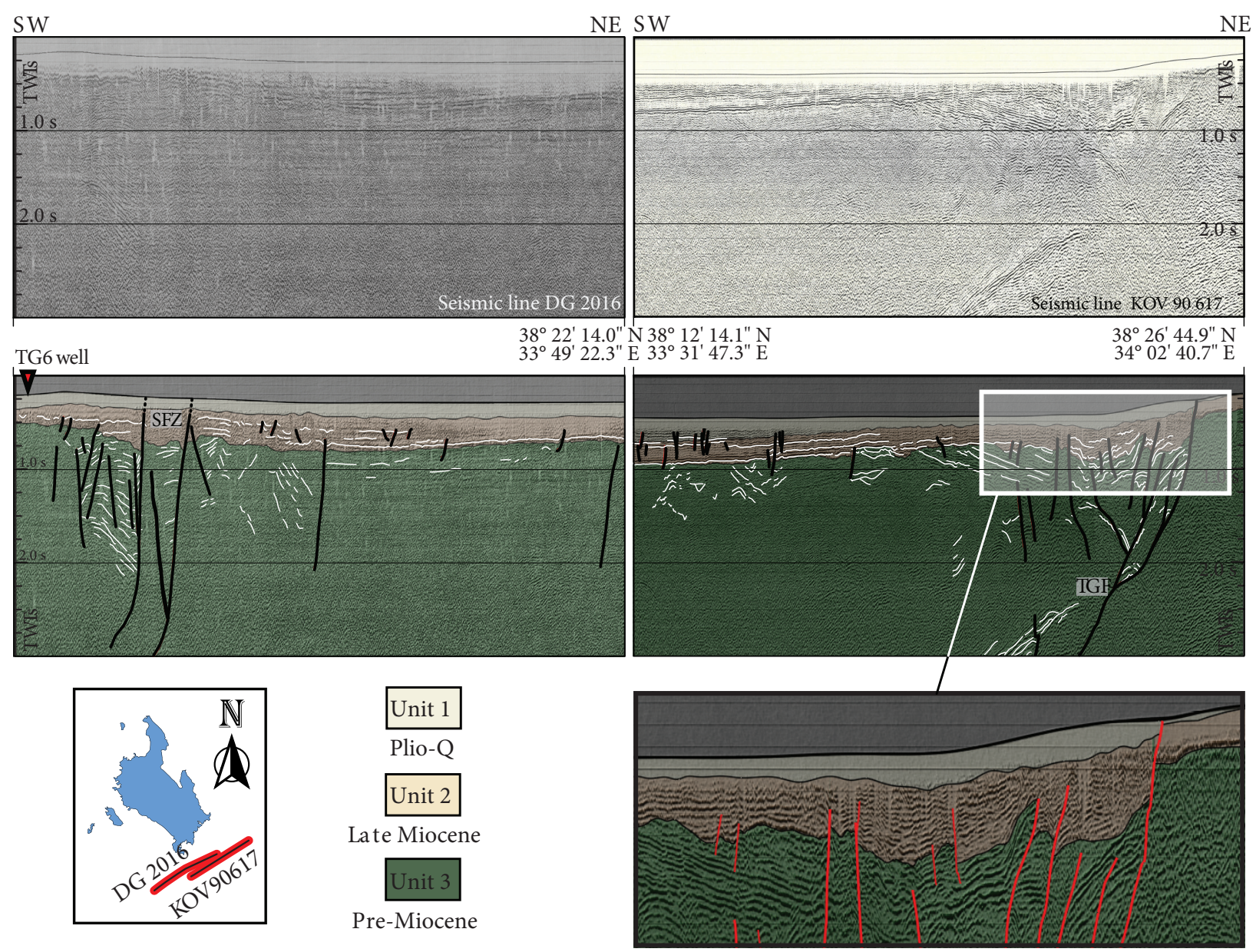

Figure 9. Seismic lines: (a) original seismic image of line DG 2016, (b) seismic interpretation in two way time (TWT) and depthconverted profile for line DG 2016, (c) original seismic image of line KOV 90 617, (d) seismic interpretation in TWT and depthconverted profile for line KOV 90 617, and (e) close-up view of the Tuz Gölü Fault cutting Plio-Quaternary units.

between 1.9 and 8.3 cal. kyr BP (Kashima 2002), covering and isolating the relicts of LGM shorelines.

\section{Discussion}

\subsection{Late Miocene change from contraction to extension} Two different stress regimes can be defined along the fault zones of the Tuz Gölü Basin since the Miocene. These regimes dictated the earlier contractional phase of deformation of the plateau interior, which was superseded by extensional processes that caused the present-day characteristics of the Tuz Gölü Basin. The earlier regime, which affected bedrock units but not cover units, was characterized by NNW-SSE to NE-SW compression. This regime induced dextral strike-slip motion along the Yeniceoba and Tuz Gölü fault zones, and was responsible for regional shortening affecting the bedrock units. Importantly, the lower ignimbrite layer, the Pliocene limestones, and the Quaternary alluvium seal these deformed bedrock units and the contractional deformation via an angular unconformity. In contrast, these cover units are almost horizontal and show no signs of contraction. Based on our age determination for the ignimbrite, we determined that the contractional deformation phase must have ended by $6.81 \pm 0.24 \mathrm{Ma}$.

The next deformation phase that has affected the region to the present day has been characterized by NNESSW to NE-SW tension, generating NW-striking normal faults, which reactivated the Yeniceoba and Tuz Gölü fault zones and formed the Cihanbeyli Fault Zone. The similar characteristics between the normal faults cutting the lower ignimbrite level, the limestones, and the Quaternary alluvium indicate that the current tectonic deformation regime has been characterized by NE-SW extension.

The change in deformation regime recorded by the structures and the kinematic indicators is also supported by the seismic reflection data. The sediment thicknesses 

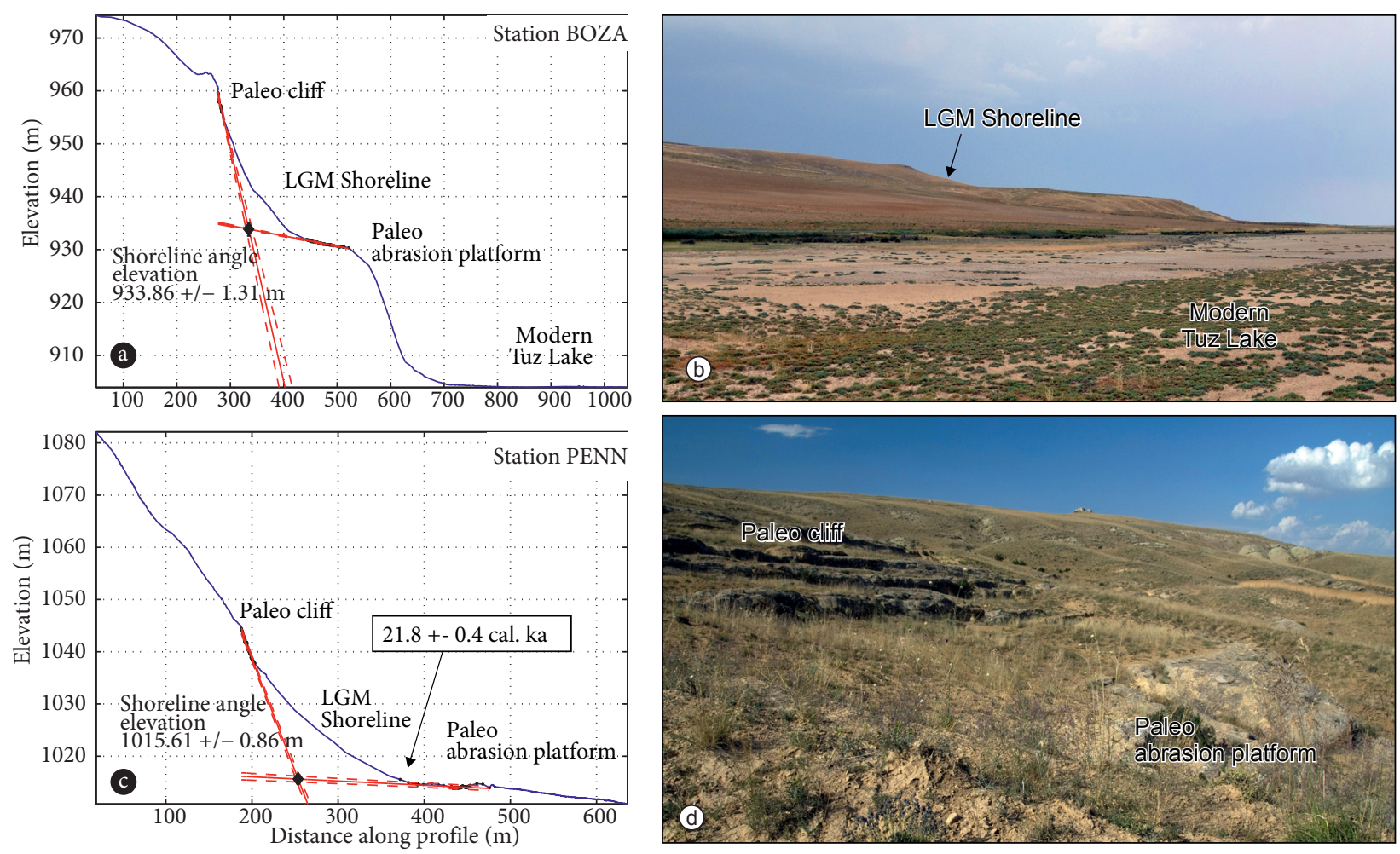

Figure 10. Examples of topographic profiles and field photos of Pleistocene shorelines of the Tuz Gölü Lake. (a \& b) Site south of the town of Bozan. To determine the elevation of the shoreline angle, which is covered by colluvium, the outcropping parts of the paleocliff and abrasion platforms have been interpolated linearly. (c \& d) Site at the Şereflikoçhisar Peninsula. The location of the sampled stromatolitic material and calibrated radiocarbon age is shown. See text for details.

and fault geometries in the seismic lines demonstrate the onset of a Pliocene phase of extension after the shortening phase ended in Late Miocene time. By the beginning of the Pliocene, this new extensional phase had led to the development of several normal faults that offset the older structures, and to the formation of secondary accommodation structures in the western part of the Tuz Gölü Fault Zone. Moreover, the fairly symmetric, concave-upwards morphology near the Tuz Gölü Fault Zone, together with the numerous smaller normal faults, point to significant extensional recent deformation for this system. However, this extensional phase does not seem to have affected the Sultanhanı Fault Zone.

Studies from other parts of Central Anatolia have also found a change from contraction to extension during the Late Miocene. For example, a phase of shortening affected units older than Miocene in age, while Upper Miocene sediments were only deformed by normal and strike-slip faults in the eastern limb of the Isparta Angle (Schildgen et al. 2012b) and in the Akssehir Graben, $\sim 200 \mathrm{~km}$ west of Tuz Gölü (Koçyiğit et al. 2000). Similar findings concerning the timing and nature of the change in kinematics were suggested to have occurred within the
Isparta Angle, toward the coast in the Manavgat Basin (Glover \& Robertson 1998; Karabıyıkoğlu et al. 2000), and at other sites within the interior of Central Anatolia (e.g., Dirik et al. 1999; Jaffey \& Robertson 2001, 2005; Rojay \& Karaca 2008). Overall, our results from the Tuz Gölü Basin support a growing body of evidence for a regional changeover from contraction to extension in Central Anatolia during the latest Miocene.

\subsection{Relative vertical displacement of the Tuz Gölü Fault Zone}

The Pliocene lacustrine limestones, locally known as the "Kışladağ Limestones", are widespread in the Tuz Gölü Basin and thus are important marker beds for determining relative offsets across faults in the region. In the western part of the basin, these limestones are observed along the Yeniceoba and Cihanbeyli fault zones. The highest outcrop of these limestones is found at $1090 \mathrm{~m}$ between the 2 fault zones. In the eastern part of the basin, the same level is observed at $1340 \mathrm{~m}$ near Mt. Ekecek (in the eastern part of the Tuz Gölü Fault Zone). The equivalent level is present SW of Tuz Gölü Lake at an elevation of $940 \mathrm{~m}$.

Tunoğlu et al. (1995) and Beker (2002) proposed an age of around $3 \mathrm{Ma}$ for the Pliocene limestones based 
on a freshwater ostracod fauna from the western part of the basin. A consistent age range for the same limestones is obtained from 2 ignimbrite levels that bracket the limestones stratigraphically. The age of the underlying "Kizılkaya" ignimbrite is somewhat controversial, having been dated by K/Ar geochronology at $4.4 \pm 0.1 \mathrm{Ma}$ and 5.4 $\pm 1.1 \mathrm{Ma}$ by Innocenti et al. (1975), and at $5.5 \pm 0.2$ and $4.9 \pm 0.2$ Ma by Besang et al. (1977). More recently, Aydar et al. (2012) used ${ }^{40} \mathrm{Ar} /{ }^{39} \mathrm{Ar}$ geochronology on plagioclase separates to derive a plateau age of $5.19 \pm 0.07$ Ma. Our result of $5.02 \pm 0.20 \mathrm{Ma}$ is consistent with the results of Aydar et al. (2012), and provides a maximum age limit for the limestones. To provide a lower limit for their age, the overlying "Valibabatepe" ignimbrite was dated at $3 \pm 0.1$ Ma using K/Ar methods (Le Pennec et al. 1994, 2005), and Aydar et al. (2012) determined a ${ }^{40} \mathrm{Ar} /{ }^{39} \mathrm{Ar}$ plagioclase plateau age of $2.52 \pm 0.49 \mathrm{Ma}$.

Taken together, the data limit the age of the limestones to approximately between 5 and $3 \mathrm{Ma}$. The vertical displacement of limestones between the western and central part of the Tuz Gölü Basin is $150 \mathrm{~m}$, and between the eastern and central part it is $400 \mathrm{~m}$. Therefore, we can constrain an average relative vertical displacement rate with respect to the center of the Tuz Gölü Basin to be 0.03 to $0.05 \mathrm{~mm} /$ year for the western flank and 0.08 to 0.13 $\mathrm{mm} /$ year for the eastern flank since 5 to $3 \mathrm{Ma}$.

At Akhisar village, south of Aksaray, Kürçer \& Gökten (2012) estimated a vertical displacement rate of $0.05 \mathrm{~mm} /$ year based on the Kizllkaya Ignimbrite having an offset of $268 \mathrm{~m}$. Akhisar is located on a step-over zone where 2 segments of the Tuz Gölü Fault Zone overlap. The ignimbrite is exposed at an elevation of $1300 \mathrm{~m}$ on the footwall block and at $1025 \mathrm{~m}$ in the step-over zone, and probably below the surface in the hanging-wall block. A slip rate of $0.05 \mathrm{~mm} /$ year can be thus inferred for the eastern fault branch in the step-over zone, and if we consider the total slip to be partitioned equally between both overlapping faults, then the total slip rate would be $0.1 \mathrm{~mm} /$ year, consistent with the rate derived from the Pliocene limestone.

These relative displacement rates are broadly similar to local incision rates along the Kizllırmak River, which flows subparallel to the eastern shoreline of Tuz Gölü Lake about 25 to $50 \mathrm{~km}$ to the east. Doğan (2011) calculated vertical incision rates of approximately $0.08 \mathrm{~mm} /$ year averaged over the last $\sim 2 \mathrm{Ma}$ based on terrace sequences and basalt ages along the river, with variations in the incision rate ranging from 0.042 to $0.12 \mathrm{~mm} /$ year. Doğan (2011) interpreted the Kiz1lirmak incision to result from Quaternary uplift of the Anatolian plateau. However, the similarity between the average fault displacement rates along the eastern margin of the Tuz Gölü Basin and the average river incision rates could imply that movement along the faults in the Tuz Gölü-Cappadocia region are responsible for the locally observed river incision. The 2 interpretations (regional relative base level fall versus local fault control) may be linked if the normal faulting is also related to the regional-scale plateau uplift, as has been proposed for the high plateaus in Tibet (Armijo et al. 1986) and the Altiplano (Schoenbohm \& Strecker 2009; Montero Lopez et al. 2010). This interpretation further suggests that the lithospheric-scale processes responsible for uplift of the southern plateau margin (Boschi et al. 2010; Faccenna \& Becker 2010; Cosentino et al. 2012; Schildgen et al. 2012a, 2012b), which started in the Late Miocene (Cosentino et al. 2012; Schildgen et al. 2012a, 2012b), might also be responsible for the evolution of the Tuz Gölü Basin and surrounding regions.

5.3 Holocene deformation along the Tuz Gölü Fault Zone Unfortunately, geomorphic correlation among the shoreline sites is not straightforward due to the lack of an overflow level. However, the levels that we surveyed are the best-expressed shorelines, which must have formed either during the last lake highstand or perhaps during subsequent regressive periods. Thus, we tentatively associate the high position of the dated LGM shoreline at Şereflikoçhisar Peninsula with slip on an active normal fault running along its western flank causing footwall uplift. The western slopes of the peninsula site are abnormally steep, and incision has been very limited, resulting in a linear face with low sinuosity. An offshore fault running at the foot of Şereflikoçhisar Peninsula has been well imaged by TPAO seismic profiles and has been recognized both in the peninsula and running along the southern sector of the present lake (Figure 9e), which supports our onshore observations.

The main strand of the Tuz Gölü Fault Zone runs along the steep mountain front, where it affects Tertiary and older units. However, the $\sim 2-8$-kyr-old alluvial fan systems in this area are not offset by faults, which strongly suggest that this strand of the fault system has remained inactive during the Holocene. The most evident geomorphic feature that may be associated with recent tectonic activity along the Tuz Gölü Fault Zone is a 1.5-m-high scarp located immediately SW of the present lake, first described by Kashima (2002). This feature is $\sim 7.5 \mathrm{~km} \mathrm{SW}$ of the mountain front, beyond the reach of Holocene alluvial fans, and is aligned with the inferred active fault running along the western flank of Şereflikoçhisar Peninsula.

The main and western branching segments of the Tuz Gölü Fault Zone merge south of Aksaray into a single segment formed by overlapping strands separated by stepover zones that affect Quaternary lavas and cinder cones of the Hasandağ composite volcano. In this region, Kürçer \& Gökten (2012) found evidence for 2 M 6 earthquakes revealed in a paleoseismic trench and inferred a recurrence interval of $\sim 5 \mathrm{kyr}$. These observations support our findings of very limited seismic activity along the Tuz Gölü Fault Zone during the Holocene. 
Our shoreline data together with geomorphic observations suggest that the Holocene activity of the Tuz Gölü Fault Zone has been localized on a NW-SE striking fault running along the western flank of Şereflikoçhisar Peninsula and extending SE for at least $60 \mathrm{~km}$. The main strand of the Tuz Gölü Fault Zone running along the mountain front appears to have been inactive during the Holocene, as no evidence of displaced alluvial fans could be found. The active strand is $\sim 7-11 \mathrm{~km}$ from the mountain front, suggesting that deformation has migrated into the basin.

Such a migration of the deformation towards the interior of an extensional basin is common in continental rift systems (e.g., Ebinger \& Scholz 2011). For example, in the northern Kenya Rift, such a migration of faulting activity is accompanied by an important increase in the strain rate, which has been interpreted to result from crustal thinning, asthenospheric upwelling, and thermal weakening, ultimately leading to localization of the deformation along the inner part of the rift system (Melnick et al. 2012). Although the tectonic setting of the Tuz Gölü Basin is quite different from the African Rift, upwelling of asthenospheric material through lithospheric slab breaks and tears has been interpreted from seismic tomography below Tuz Gölü (Biryol et al. 2011) and related to uplift patterns in the region immediately to the south (Cosentino et al. 2012; Schildgen et al. 2012a, 2012b). Thus, the migration of deformation towards the interior of the Tuz Gölü basin might also reflect the onset of crustal thinning associated with lithospheric-scale processes such as propagation of a slab tear.

\section{Conclusions}

Considering our field observations, kinematic data, and seismic reflection-line interpretations, 2 different deformation regimes can be identified for the Tuz Gölü Basin area. The first regime is characterized by NNW-SSE to NE-SW shortening that affected pre-Upper Miocene units during a regional compressional stress regime. This phase of deformation is manifested by a curvilinear trend of NW-SE to E-W striking folds from the Tuz Gölü Basin to the Ankara region, E-W striking thrust and back-thrust faults that superimpose pre-Upper Miocene units onto one another, and NW-striking dextral strike-slip faults that juxtapose Oligo-Miocene and ophiolitic mélange units. The NE-SW to NNW-SSE contractional tectonic period prevailed until the Late Miocene. We constrain the end of contraction to before $6.81 \pm 0.24 \mathrm{Ma}$, based on our new ${ }^{40} \mathrm{Ar} /{ }^{39} \mathrm{Ar}$ dating of an ignimbrite within the uppermost Miocene-Pliocene fluvio-lacustrine sediments that seal the shortened rock units via an angular unconformity and do not bear any signs of sustained contraction. The subsequent $\mathrm{N}-\mathrm{S}$ to $\mathrm{NE}-\mathrm{SW}$ extensional tectonic regime was initiated during the Pliocene and continues to the present day.

Our interpretation of the seismic reflection profiles reveals no basin terminations for the Miocene units, either for the Tuz Gölü Fault Zone or the Sultanhanı Fault Zone. Thus, these systems did not constitute basinbounding faults during the Miocene. The Sultanhanı Fault Zone constitutes a southwest-dipping fault set that probably acted as an extension to a strike-slip intrabasinal fault during the Late Oligocene and Miocene time, later sealed by Pliocene deposits. The Tuz Gölü Fault Zone is a complex fault system that was initiated as a horst possibly during the Neogene, underwent a phase of shortening that continued into Messinian time, and was followed by renewed and ongoing extension.

As Pliocene limestones crop out in several localities within the basin, we used these 3-5-million-year-old marker horizons to calculate relative vertical displacement rates with respect to the central parts of the basin. Taking into account the vertical offset of the limestones across major fault systems in the area, the average relative vertical displacement rate is 0.03 to $0.05 \mathrm{~mm} /$ year for the western flank of the basin relative to the center, and 0.08 to 0.13 $\mathrm{mm} /$ year for the eastern flank relative to the center.

At Şereflikoçhisar Peninsula, dated shorelines and seismic sections indicate that the normal fault controlling the western margin of the peninsula was active during the Holocene. The lack of normal faults cutting the alluvial fans located on the main strand of the Tuz Gölü Fault Zone suggests that deformation migrated into the basin during the Holocene.

Overall our investigations highlight a major kinematic changeover from contraction that ended in the Late Miocene to extension since the Pliocene in the center of the Central Anatolian Plateau, which may have resulted from changing geodynamic boundary conditions.

\section{Acknowledgments}

This work is part of the Vertical Anatolian Movements Project (VAMP), funded by the TOPOEUROPE initiative of the European Science Foundation, including contributions by TÜBİTAK (Project: 107Y333) to A. Çiner, the German Science Foundation (Grants: STR373/20-1 and 25-1) to M. Strecker, and the Netherlands Organization for Scientific Research (NWO) to G. Bertotti. Seismic lines were kindly provided by the General Directorate of Petroleum Affairs (data set obtained by the Turkish Petroleum Corporation (TPAO) in the 1990 and 1991 campaigns). We are grateful to F. Pepe for providing GeoSuite AllWorks ${ }^{\circledast}$ for seismic interpretations. A. Kutluay and all VAMP participants are thanked for their assistance in the fieldwork and discussions. The authors also appreciate U. Doğan, M. Karabıyıkoğlu, E. Koşun, and C. Yıldırım for their valuable comments and suggestions to improve this manuscript. 


\section{References}

Altunel, E. \& Barka, A. 1998. Neotectonic activity of Eskişehir fault zone between İnönü and Sultandere. Geological Bulletin of Turkey 41, 41-52 [in Turkish with English abstract].

Angelier, J. 1991. Inversion of field data in fault tectonics to obtain regional stress. III: A new rapid direct inversion method by analytical means. Geophysical Journal International 103, 63-76.

Angelier, J. 1994. Fault slip analysis and paleostress reconstruction. In: Hancock, P.L. (ed), Continental Deformation. Pergamon, Oxford, 101-120.

Arıkan, Y. 1975. The geology and petroleum prospects of the Tuz Gölü basin. Mineral Research and Exploration Institute of Turkey (MTA) Bulletin 85, 17-38.

Armijo, R., Tapponnier, P., Mercier, J.L. \& Han, T.L. 1986. Quaternary extension in southern Tibet: field observations and tectonic implications. Journal of Geophysical Research 91, 13803-13872.

Aydar, E., Schmitt, A.K., Çubukçu, H.E., Akin, L., Ersoy, O., Sen, E., Duncan, R.A. \& Atici, G. 2012. Correlation of ignimbrites in the central Anatolian volcanic province using zircon and plagioclase ages and zircon compositions. Journal of Volcanology and Geothermal Research 213-214, 83-97.

Barka, A.A. 1992. The North Anatolian fault zone. Annales Tectonicae 6, 164-195.

Barka, A.A. \& Reilinger, R. 1997. Active tectonics of the Mediterranean region: deduced from GPS, neotectonic and seismicity data. Annali di Geophisica 11, 587-610.

Beker, K. 2002. Biostratigraphic and Chronostratigraphic Investigation of Ostracoda assemblage of Insuyu limestone (Karapinar) Konya). MSc Thesis, Hacettepe University, Ankara-Turkey [in Turkish with English abstract, unpublished].

Besang, C., Eckhardt, F.J., Harre, W., Kreuzer, G. \& Muller, P. 1977. Radiometrische Alterbestimmungen an neogenenen Eruptivgesteinen der Turkei. Geologisches Jahrbuch 25, 3-36.

Biryol, C.B., Beck, S.L., Zandt, G. \& Özacar, A.A. 2011. Segmented African lithosphere beneath the Anatolian region inferred from teleseismic P-wave tomography. Geophysical Journal International 184, 1037-1057.

Boschi, L., Faccenna, C., \& Becker, T.W. 2010. Mantle structure and dynamic topography in the Mediterranean Basin. Geophysical Research Letters 37, L20303, doi:10.1029/2010GL045001.

Butzer, K.W. 1971. Recent history of an Ethiopian delta: the Omo River and the level of Lake Rudolf. University of Chicago Department of Geography, Paper No. 136.

Çemen, İ. \& Dirik, K. 1992. Tuzgölü havzasının kuzeydoğu kısmının stratigrafisi, yapısal jeolojisi ve jeoloji tarihi. Turkish Petroleum Corporation (TPAO), Report No. 3115 [in Turkish, unpublished].

Çemen, İ., Göncüoğlu, M.C. \& Dirik, K. 1999. Structural evolution of the Tuzgölü basin in Central Anatolia, Turkey. Journal of Geology 107, 693-706.
Cosentino, D., Schildgen, T.F., Cipollari, P., Faranda, C., Gliozzi, E., Hudáčková, N., Lucifora, S. \& Strecker, M.R. 2012. Late Miocene surface uplift of the southern margin of the Central Anatolian Plateau, Central Taurides, Turkey. Geological Society of America Bulletin 124, 133-145.

Dellaloğlu, A. \& Aksu, R. 1984. Kulu-Şereflikoçhisar-Aksaray dolayının jeolojisi ve petrol olanakları. Turkish Petroleum Corporation (TPAO), Report No. 2020 [in Turkish, unpublished].

Delvaux, D., Moeys, R., Stapel, G., Petit, C., Levi, K., Miroshnichenko, A., Ruzhich, V. \& San'kov, V. 1997. Paleostress reconstruction and geodynamics of the Baykal region. Tectonophysics 282, $1-38$.

De Mets, C., Gordon, R.G., Argus, D.F. \& Stein, S. 1990. Current plate motions, Geophysical Journal International 102, 425-478.

Derman, S., Rojay, B., Güney, H. \& Yıldız, M. 2003. New sedimentological data on the evolution of ŞereflikoçhisarAksaray fault zone. Turkish Association of Petroleum Geologists Special Publication 5, 47-70 [in Turkish with English abstract].

Dhont, D., J. Chorowicz, J., Yürür, T., Froger, J.L., Köse, O. \& Gündoğdu, N. 1998. Emplacement of volcanic vents and geodynamics of Central Anatolia, Turkey. Journal of Volcanology and Geothermal Research 85, 33-54.

Dilek, Y. \& Whitney, D.L. 2000. Cenozoic crustal evolution in Central Anatolia: extension, magmatism and landscape development. In: Panayides, I., Xenophontos, C., and Malpas, J. (eds), Proceedings of the Third International Conference on the Geology of the Eastern Mediterranean, September 1998, Nicosia, Cyprus Geological Survey, 183-192.

Dilek, Y., Whitney, D.L. \& Tekeli, O. 1999. Links between tectonic processes and landscape morphology in an alpine collision zone, south-central Turkey. Annals of Geomorphology ( $Z$. Geomorph. N.F.) 118, 147-164.

Dirik, K. \& Erol, O. 2003. Tectonomorphologic evolution of Tuzgölü and surrounding area, central Anatolia-Turkey. Turkish Association of Petroleum Geologists Special Publication 5, 27-46 [In Turkish with English abstract].

Dirik, K. \& Göncüoğlu, M.C. 1996. Neotectonic characteristics of Central Anatolia. International Geology Review 38, 807-817.

Dirik, K., Göncüoğlu, M.C. \& Kozlu, H. 1999. Stratigraphy and preMiocene tectonic evolution of the southwestern part of the Sivas Basin, Central Anatolia, Turkey. Geological Journal 34, 303-319.

Dirik, K., Akıl, B. \& Özsayın, E., 2005. Eskişehir-Sultanhanı Fay Sistemi'nin Sivrihisar-Cihanbeyli Kesimi'nin Özellikleri, Orta Anadolu-Türkiye. Eskişehir Fay Zonu ve İlişkili Sistemlerin Depremselliği Çalıştayı, 28-30 April 2005, Eskişehir, Extended abstracts, 9-10 [in Turkish].

Doğan, U. 2011. Climate-controlled river terrace formation in the Kizılırmak Valley, Cappadocia section, Turkey: inferred from Ar-Ar dating of Quaternary basalts and terraces stratigraphy. Geomorphology 126, 66-81. 
DSİ. 1998. Van gölü ve çevresindeki suların izotopik ve kimyasal içeriklerinin belirlenmesi ve su dengesinin incelenmesi. T.C. Enerji ve Tabii Kaynaklar Bakanlığı, Ankara [in Turkish].

Duru, M. \& Gökçen, N. 1985. The Lower Paleogene ostracoda fauna of south of Polatlı (SW Ankara) including five new species, and its stratigraphic evaluation. Bulletin of Geological Society of Turkey 28, 147-158 [in Turkish with English abstract].

Ebinger, C. \& Scholz, C.A. 2011. Continental Rift Basins: The East African Perspective, Tectonics of Sedimentary Basins. John Wiley \& Sons, pp. 183-208.

Erol, O. 1969. Tuzgölü Havzasının jeolojisi ve jeomorfolojisi. Mineral Research and Exploration Institute of Turkey (MTA) Report No. 4220 [in Turkish, unpublished].

Faccenna, C. \& Becker, T.W. 2010. Shaping mobile belts by smallscale convection. Nature 465, 602-605.

Faccenna, C., Funiciello, F., Giardini, D. \& Lucente, P. 2001. Episodic back-arc extension during restricted mantle convection in the Central Mediterranean. Earth and Planetary Science Letters 187, 105-116.

Faccenna, C., Bellier, O., Martinod, J., Piromallo, C. \& Regard, V. 2006. Slab detachment beneath eastern Anatolia: a possible cause for the formation of the North Anatolian fault. Earth and Planetary Science Letters 242, 85-97.

Fernández-Blanco, D., Bertotti, G. \& Çiner, A. 2013. Cenozoic tectonics of the Tuz Gölü Basin (Central Anatolia Plateau, Turkey). In: Çiner, A., Strecker, M. \& Bertotti, G. (eds), "Late Cenozoic Evolution of the Central Anatolia." Turkish Journal of Earth Sciences, 22, 715-738.

Gans, C.R., Beck, S.L., Zandt, G., Biryol, C.B. \& Ozacar, A.A. 2009. Detecting the limit of slab break-off in central Turkey: new high-resolution Pn tomography results. Geophysical Journal International 179, 1566-1577.

Garcin, Y., Junginger, A., Melnick, D., Olago, D.O., Strecker, M.R. \& Trauth, M.H. 2009. Late Pleistocene-Holocene rise and collapse of Lake Suguta, northern Kenya Rift. Quaternary Science Reviews 28, 911-925.

Garcin, Y., Melnick, D., Strecker, M.R., Olago, D., \& Tiercelin, J.J. 2012. East African mid-Holocene wet-dry transition recorded in palaeo-shorelines of Lake Turkana, northern Kenya Rift. Earth and Planetary Science Letters 331-332, 322-334.

Genç, Y. \& Yürür, M.T. 2010. Coeval extension and compression in Late Mesozoic -Recent thin-skinned extensional tectonics in central Anatolia, Turkey. Journal of Structural Geology 32, 623-640.

Glover, C. \& Robertson, A. 1998. Neotectonic intersection of the Aegean and Cyprus tectonic arcs: extensional and strike-slip faulting in the Isparta Angle, SW Turkey. Tectonophysics 298, 103-132.

Göncüoglu, M.C., Toprak, V., Kuscu, I., Erler, A. \& Olgun E. 1991. Geology of the Western Part of the Central Anatolian Massif, Part 1: Southern Section. Turkish Petroleum Corporation (TPAO) Report No 2909 [in Turkish, unpublished].
Göncüoğlu, M.C., Erler, A., Toprak, V., Yalınız, K., Olgun, E., \& Rojay, B. 1992. Orta Anadolu Masifinin Batı Bölümünün Jeolojisi. Bölüm 2: Orta Kesim. Turkish Petroleum Corporation (TPAO) Report No. 3535 [in Turkish, unpublished].

Göncüoğlu, M.C., Dirik, K., Erler, A., Yalınız, K., Özgül, L. \& Çemen, İ. 1996. Tuzgölü Havzası Batı Kısmının Temel Jeolojik Sorunları. Turkish Petroleum Corporation (TPAO) Report No. 3753 [in Turkish, unpublished].

Görür, N. \& Derman, A.S. 1978. Tuzgölü-Haymana Havzasının Stratigrafikve Tektonik Analizi. Turkish Petroleum Corporation (TPAO) Report No. 1514 [in Turkish, unpublished].

Görür, N., Oktay, F.Y., Seymen, İ. \& Şengör, A.M.C. 1984. Paleotectonic evolution of the Tuzgölü basin complex, Central Turkey: sedimentary record of a Neo-Tethyan closure. In: Dixon, J.E. \& Robertson, A.H.F. (eds), The Geological Evolution of the Eastern Mediterranean. Journal of the Geological Society of London Special Publication, 17, 467-482.

Gülen, L., Barka, A.A. \& Toksöz, M.N. 1987. Continental collision and related complex deformation: Maraş triple junction and surrounding structures, SE Turkey. Earthsciences 14, 319-336 [in Turkish with English abstract].

Hess, J.C. \& Lippolt H.J. 1994. Compilation of K-Ar measurements on HD-B1 standard biotite, 1994 status report. In: Odin, G.S. (ed), Phanerozoic Time Scale, Bulletin of Liaison and Information, IUGS Subcommission on Geochronology, Paris, pp.19-23.

Innocenti, F., Mazzuoli, R., Pasquarè, G. Radicati di Brozolo, F. \& Villari, L. 1975. The Neogene calc-alkaline volcanism of Central Anatolia: geochronological data on Kayseri-Nigde area. Geological Magazine 112, 349-360.

Ishizuka, O., Yuasa M. \& Uto K. 2002. Evidence of porphyry coppertype hydrothermal activity from a submerged remnant back-arc volcano of the Izu-Bonin arc: implication for the volcanotectonic history of back-arc seamounts. Earth and Planetary Science Letters 198, 381-399.

Jaffey, N. \& Robertson, A.H.F. 2001. New sedimentological and structural data from the Ecemiş fault zone, southern Turkey: implications for its timing and offset of the Cenozoic tectonic escape of Anatolia. Journal of the Geological Society 158, 367378.

Jaffey, N. \& Robertson, A. 2005. Non-marine sedimentation associated with Oligocene - recent exhumation and uplift of the Central Taurus Mountains, S Turkey. Sedimentary Geology 173, 53-89.

Karabiyikoğlu, M., Çiner, A., Monod, O., Deynoux, M., Tuzcu, S. \& Örçen, S. 2000. Tectono-sedimentary evolution of the Miocene Manavgat Basin, Western Taurids, Turkey. In: Bozkurt, E., Winchester, J.A. \& Piper, J.A.D. (eds), Tectonics and Magmatism in Turkey and the Surrounding Area. Geological Society of London Special Publication 173, 271-294.

Kashima, K. 2002. Environmental and climatic changes during the last 20,000 years at Lake Tuz, central Turkey. Catena 48, 3-20. 
Koçyiğit, A. 1991. Changing stress orientation in progressive intracontinental deformation as indicated by the neotectonics of the Ankara region (NW of Central Anatolia). Turkish Association of Petroleum Geologists Bulletin 3, 48-55.

Koçyiğit, A. 1992. Southward-vergent imbricate thrust zone in Yuvaköy: a record of the latest compressional event related to the collisional tectonic regime in Ankara-Erzincan suture zone. Turkish Association of Petroleum Geologists Bulletin 4, 111-118.

Koçyiğit, A. 2003. General neotectonic characteristics and seismicity of Central Anatolia. Turkish Association of Petroleum Geologists Special Publication 5, 1-26 [in Turkish with English abstract].

Koçyiğit, A. \& Beyhan, A. 1998. A new intracontinental transcurrent structure: the Central Anatolian fault zone, Turkey. Tectonophysics 284, 317-336.

Koçyiğit, A., Ünay, E. \& Saraç, G. 2000. Episodic graben formation and extensional neotectonic regime in west Central Anatolia and the Isparta angle: a case study in the Akşehir-Afyon Graben, Turkey. In: Bozkurt, E., Winchester, J.A. \& Piper, J.D.A. (eds), Tectonics and Magmatism in Turkey and the Surrounding Area. Geological Society of London Special Publication 173, 405-421.

Koçyiğit, A., Rojay, B., Cihan, M. \& Özacar, A. 2001. The June 6, 2000, Orta (Çankırı, Turkey) earthquake: sourced from a new antithetic sinistral strike-slip structure of the North Anatolian fault system, the Dodurga fault zone. Turkish Journal of Earth Sciences 10, 69-82.

Kutluay, A., Dirik, K., Çiner, A. \& Bertotti, G. 2010. 3D architecture and Miocene evolution of the Tuz Gölü Basin in Central Anatolian Plateau, Turkey. EGU General Assembly, Geophysical Research Abstracts 12, 15042.

Kuzucuoğlu, C., Christol, A., Mouralis, D., Doğu, A.F., Akköprü, E., Fort, M., Brunstein, D., Zorer, H., Fontugne, M., Karabıyıkoğlu, M., Scaillet, S., Reyss, J.L. \& Guillou, H. 2010. Formation of the upper Pleistocene terraces of Lake Van (Turkey). Journal of Quaternary Science 25, 1124-1137.

Küçükuysal, C., Engin, B., Türkmenoğlu, A.G., \& Aydaş, C. 2011. ESR dating of calcrete nodules from Bala, Ankara (Turkey): preliminary results. Applied Radiation Isotopes 69, 492-499.

Kürçer, A. \& Gökten, E. 2011. The first paleoseismological data from southern part of Tuzgölü Fault Zone, Central Anatolia, Turkey. $64^{\text {th }}$ Geological Congress of Turkey, Abstracts Book, 7-8.

Kürçer, A. \& Gökten, E. 2012. Paleoseismological three dimensional virtual photography method; a case study: Bağlarkayası-2010 trench, Tuz Gölü fault zone, Central Anatolia, Turkey. In: Sharkov, E. (ed), Tectonics - Recent Advances), InTech, pp. 201228. DOI: $10.5772 / 48194$

Kürçer, A., Gökten, E. \& Yeleser, L. 2011. Tuzgölü Fay Zonu Üzerinde Paleosismolojik Hendek Çalışmaları, Orta Anadolu, Türkiye. ATAG-15 Aktif Tektonik Araştırma Grubu 15. Toplantısi (15 ${ }^{\text {th }}$ Meeting of Active Tectonics Research Group), 19-22 October 2011, Abstracts, 13-14 [in Turkish].

Le Pennec, J.L., Bourdier, J.L., Froger, J.L., Temel, A., Camus, G. \& Gourgaud, A. 1994. Neogene ignimbrites of the Nevşehir plateau (Central Turkey): stratigraphy, distribution and source constraints. Journal of Volcanology and Geothermal Research 63, 59-87.
Le Pennec, J.L., Temel, A., Froger, J.L., Şen, S., Gourgaud, A. \& Bourdier, J.L. 2005. Stratigraphy and age of the Cappadocia ignimbrites, Turkey: reconciling field constraints with paleontologic, radiochronologic, geochemical and paleomagnetic data. Journal of Volcanology and Geothermal Research 141, 45-64.

Mart, Y. \& Woodside, J. 1994. Preface: tectonics of the Eastern Mediterranean. Tectonophysics 234, 1-3.

McKenzie, D. 1978. Active tectonics of the Alpine-Himalayan belt: the Aegean Sea and surrounding regions. Geophysical Journal of the Royal Astronomical Society 55, 217-254.

Melnick, D., Garcin, Y., Quinteros, J., Strecker, M.R., Olago, D. \& Tiercelin, J.J. 2012. Steady rifting in northern Kenya inferred from deformed Holocene lake shorelines of the Suguta and Turkana basins. Earth and Planetary Science Letters 331-332, 335-346.

Meulenkamp, J.E, Wortel, W.J.R., Van Wamel, W.A., Spakman, W. \& Hoogerduyn Strating, E. 1988. On the Hellenic subduction zone and geodynamic evolution of Crete in the late middle Miocene. Tectonophysics 146, 203-215.

Montero Lopez, M.C., Hongn, F.D., Strecker, M.R., Marrett, R., Seggiaro, R. \& Sudo, M. 2010. Late Miocene-early Pliocene onset of N-S extension along the southern margin of the Central Andean Puna Plateau: evidence from magmatic, geochronological and structural observations. Tectonophysics 494, 48-63.

Naruse, T., Kitagawa, H. \& Hisashi, M. 1997. Lake level changes and development of alluvial fans in Lake Tuz and the Konya basin during the last 24000 years on the Anatolian plateau, Turkey. Japan Review 8, 65-84.

Ocakoğlu F. \& Açıkalın S. 2009. Late Pleistocene fault-induced uplift and consequent fluvial response in Eskişehir fault zone, NW Anatolia. Zeitschrift für Geomorphologie 53, 121-136.

Ogg, J.G., Ogg, G. \& Gradstein, F.M. 2008. The Concise Geologic Time Scale. Cambridge University Press, Cambridge.

Özcan, A., Göncüoğlu, M.C. \& Turhan, N. 1989. Kütahya-ÇiftelerBayat-İhsaniye Yöresinin Temel Jeolojisi. Mineral Research and Exploration Institute of Turkey (MTA) Report No. 8118 [in Turkish, unpublished].

Özcan, A., Göncüoğlu, M.C., Turhan, N., Uysal, Ş. \& Şentürk, K. 1990a. Paleozoic evolution of the Kütahya-Bolkardağı Belt. METU Journal of Pure and Applied Sciences 21, 211-220.

Özcan, A., Göncüoğlu, M.C., Turhan, N., Şentürk, K., Uysal, Ş. \& Işık, A. 1990b. Konya-Kadınhanı-Ilgın Dolayının Temel Jeolojisi. Mineral Research and Exploration Institute of Turkey (MTA) Report No. 9535 [in Turkish, unpublished].

Özsayın, E. 2007. Neogene-Quaternary structural evolution of İnönüEskişehir fault system between Yeniceoba-Cihanbeyli (KonyaTurkey). PhD Thesis, Hacettepe University, Ankara-Turkey [in Turkish with English abstract].

Özsayın, E. \& Dirik, K. 2005. Cihanbeyli Fay Zonu’nun (EskişehirSultanhanı Fay Sistemi'nin güney segmenti) Kuvaterner aktivitesi. ATAG-9 Aktif Tektonik Araştırma Grubu 9. Toplantısı ( $9^{\text {th }}$ Meeting of Active Tectonics Research Group), 22-24 September 2005, Abstracts, p. 41 [in Turkish]. 
Özsayın, E. \& Dirik, K. 2007. Quaternary activity of the Cihanbeyli and Yeniceoba fault zones: İnönü-Eskişehir fault zystem, Central Anatolia. Turkish Journal of Earth Sciences 16, 471-492.

Özsayın, E. \& Dirik, K. 2011. The role of oroclinal bending in the structural evolution of the Central Anatolian plateau: evidence from a regional changeover of shortening to extension. Geologica Carpathica 62, 345-359.

Papazachos, B.C. \& Comninakis, P.E. 1971. Geophysical and tectonic features of the Aegean arc. Journal of Geophysical Research 76, 8517-8533.

Reilinger, R.E, McClusky, S.C., Oral, M.B., King, W. \& Toksöz, M.N. 1997. Global positioning system measurements of presentday crustal movements in the Arabian-Africa-Eurasia plate collision zone. Journal of Geophysical Research 102, 9983-9999.

Rigo de Righi, M. \& Cortesini, A. 1959. Regional Studies of the Central Anatolian Basin. Petrol İşleri Report No. 11 [unpublished].

Roberts, N., Black, S., Boyer, P., Eastwood, W.J., Griffiths, H.I., Lamb, H.F., Leng, M.J., Parish, R., Reed, J.M., Twigg, D. \& Yiğitbaşoğlu, H. 1999. Chronology and stratigraphy of Late Quaternary sediments in the Konya Basin, Turkey: results from the KOPAL Project. Quaternary Science Reviews 18, 611-630.

Rojay, B. \& Karaca, A. 2008. Post-Miocene deformation in the south of the Galatean Volcanic Province, NW of Central Anatolia (Turkey). Turkish Journal of Earth Sciences 17, 653-672.

Sarikaya, M.A., Zreda, M., Çiner, A. \& Zweck, C. 2008. Cold and wet Last Glacial Maximum on Mount Sandıras, SW Turkey, inferred from cosmogenic dating and glacier modeling. Quaternary Science Reviews 27, 769-780.

Sarikaya, M.A., Zreda, M. \& Çiner, A. 2009. Glaciations and paleoclimate of Mount Erciyes, central Turkey, since the Last Glacial Maximum, inferred from ${ }^{36} \mathrm{Cl}$ cosmogenic dating and glacier modeling. Quaternary Science Reviews 28, 2326-2341.

Schemmel, F., Mikes, T., Rojay, B. \& Mulch, A. 2013. The impact of topography on isotopes in precipitation across the Central Anatolian Plateau (Turkey). American Journal of Science 313: $61-80$.

Schildgen, T.F., Cosentino, D., Bookhagen, B., Niedermann, S., Yildirim, C., Echtler, H.P., Wittmann, H. \& Strecker, M.R. 2012a. Multi-phase uplift of the southern margin of the Central Anatolian plateau: a record of tectonic and upper mantle processes. Earth and Planetary Science Letters 317-318, 85-95.

Schildgen, T.F., Cosentino, D., Caruso, A., Buchwaldt, R., Yildirim, C., Rojay, B., Bowring, S.A., Echtler, H. \& Strecker, M.R. 2012b. Surface expression of Eastern Mediterranean slab dynamics: neogene topographic and structural evolution of the southwest margin of the Central Anatolian plateau, Turkey. Tectonics 31, TC2005, doi: 10.1029/2011TC003021.

Schoenbohm, L., \& Strecker, M. 2009. Extension within the PunaAltiplano plateau: evidence from the plateau margin, NW Argentina. Tectonics 28, TC5008, doi: 10.1029/2008TC002341.

Şengör, A.M.C. 1979. The North Anatolian transform fault: its age, offset and tectonic significance. Journal of the Geological Society of London 136, 269-282.
Şengör, A.M.C. \& Yilmaz, Y. 1981. Tethyan evolution of Turkey: a plate tectonic approach. Tectonophysics 75, 181-241.

Şengör, A.M.C., Görür, N. \& Şaroğlu, F. 1985. Strike-slip faulting and related basin formation in zones of tectonic escape: Turkey as a key study. In: Biddle, K.T. \& Christie-Blick, N. (eds), Strikeslip Deformation, Basin Formation, and Sedimentation. SEPM Society for Sedimentary Geology Special Publications 37, 227264.

Sudo, M., Uto, K., Anno, K., Ishizuka, O. \& Schiumi, S. 1998. SORI93 biotite: a new mineral standard for $\mathrm{K}-\mathrm{Ar}$ dating. Geochemical Journal 32, 49-58.

Tunoğlu, C., Temel, A. \& Gençoğlu, H. 1995. Pliocene ostracoda association and environmental characteristics of Sivrihisar (Eskişehir) - Central Anatolia. In: Riha, J. (ed), Ostracoda and Biostratigraphy, Proceedings of the $12^{\text {th }}$ International Ostracoda Symposium, Rotterdam-Netherlands, pp. 265-275.

Ünalan, G., Yüksel, V., Tekeli, T., Gönenç, O., Seyirt, Z. \& Hüseyin, S. 1976. The stratigraphy and paleogeographical evolution of the Upper Cretaceous-Lower Tertiary sediments in the HaymanaPolatlı region (SW of Ankara). Bulletin of the Geological Society of Turkey 19, 159-176 [in Turkish with English abstract].

Uto, K., Ishizuka, O., Matsumoto, A., Kamioka H., \& Togashi S. 1997. Laser-heating 40Ar/39Ar dating system of the Geological Survey of Japan: system outline and preliminary results. Bulletin of the Geological Survey of Japan 48, 23-46.

Uygun, A., Yaşar, M., Erkan, M.C., Bas, H., Çelik, E., Aygün, M., Bilgiç, T., Kayakıran, S. \& Ayok, F. 1982. Tuzgölü Havzası Projesi [Tuzgölü Basin Project]. Mineral Research and Exploration Institute of Turkey (MTA) Report No. 2 [unpublished].

Whitney, D.L. \& Dilek, Y. 1997. Core complex development in Central Anatolia, Turkey. Geology 25, 1023-1026.

Yetiş, C. 1978. Geology of the Çamardı (Niğde) region and the characteristics of the Ecemiş fault zone between Madenboğaz and Kamışlı. İstanbul University Faculty of Science Bulletin B43, 41-61.

Yetiş, C. 1984. New observations on the age of the Ecemiş fault. In: Tekeli, O. \& Göncüoğlu, M.C. (eds), Geology of the Taurus Belt. Mineral Research and Exploration Institute of Turkey (MTA) Special Publications, pp. 386-394.

Yetiş, C. \& Demirkol, C., 1984. Geotectonic evolution of the Ecemiş fault zone. Earth Sciences 11, 1-12.

Yildirim, C., Schildgen, T.F., Echtler, H., Melnick, D. \& Strecker, M.R. 2011. Late Neogene orogenic uplift in the Central Pontides associated with the North Anatolian fault - implications for the northern margin of the Central Anatolian plateau, Turkey. Tectonics 30, TC5005, doi: 10.1029/2010TC002756.

Zreda, M., Çiner, A. Sarikaya, M.A., Zweck, C. \& Bayari, S. 2011. Remarkably extensive Early Holocene glaciation in Aladağlar, Central Turkey. Geology 39, 1051-1054. 